\title{
A STRATEGIC MARKETING PERSPECTIVE ON ENTREPRENEURS \& INNOVATION
}

\author{
Fernando Antonio Monteiro Christoph D'Andrea \\ PhD Candidate in Business Administration / Marketing \\ Business School - Federal University of Rio Grande do Sul - EA-UFRGS \\ Porto Alegre, RS, Brazil \\ dodandrea@gmail.com \\ Fernando Bins Luce \\ Full Professor \\ Business School - Federal University of Rio Grande do Sul - EA-UFRGS \\ Porto Alegre, RS, Brazil \\ fernando.luce@ufrgs.br
}

Objective: To uncover the underlying and, to this time, unexplored connections between the theories of Strategic Marketing and Entrepreneurship, using innovation as the underlying phenomena.

Method/Approach: This theoretical paper discusses the aforementioned literatures and shows that innovation can be seen as a connection between methodological individualism from the entrepreneurial theory of the firm and Strategic Marketing literature. The basic literature on entrepreneurship from that standpoint and the most used references in Strategic Marketing were compared.

Main Results: More than exposing the connections, the paper brings two objective results: a framework encompassing both fields' previous theoretical developments and a comparative table with theoretical concepts and original contributions, both offering paths to be followed by future theoretical and empirical research.

Theoretical and Methodological Contributions: The work contributes by presenting the complementarity among the literatures, improving interdisciplinarity, and by taking a first step to (re)insert individualism as a valid methodological approach in (Strategic) Marketing. It does so, specifically, by considering the entrepreneur as a central figure in any organization.

Relevance/Originality: This is previously unexplored territory. Some scholars discuss the importance of powerexercising individuals, but the use of the theoretically sound approach brought about by the entrepreneurial theory of the firm to discuss Strategic Marketing matters is unprecedented.

Management or Social Implications: By adopting an individualistic approach to the Strategic Marketing analysis, scholars will enhance their set of tools to understand organizational and market dynamism. It also contributes to approximate academic and practitioner's approaches.

Keywords: Strategic marketing. Entrepreneurship. Innovation. Entrepreneurial theory of the firm.

\section{$\underline{\text { How to cite the article }}$}

American Psychological Association (APA)

D'Andrea, F. A. M. C., \& Luce, F. B. (2021, July/Sept.). A strategic marketing perspective on entrepreneurs \& innovation. Brazilian Journal of Marketing, 20(3), 602-628. https://doi.org/10.5585/remark.v20i3.16322. 


\section{Introduction}

Strategic Marketing (SM) deals with the organizational approach to the market and how the company positions itself to compete and survive. Innovating is a necessary feature for survival, and it underlies, albeit not explicitly, the discussion about entrepreneurship and about SM. The figure of the entrepreneur, however, mostly remains outside the discussion on SM. Indeed the entrepreneurial role in influencing organizational decisions and the consequent market outcomes is rarely discussed.

Innovation is part of strategy and, as much as group work and innovation management remain very important, it depends on decision-making that is naturally and exclusively individual and human, entrepreneurial. This mostly neglected relationship between entrepreneurship and innovation (Bylund, 2016) must be further explored by scholars on marketing, especially because of its deep implications to SM. The absence of the theory of the entrepreneur in SM is what this paper explores and tries to bridge.

Innovation is also core to marketing theory (Day \& Wensley, 1983), and SM in particular sees innovation as fundamental (Finoti, Didonet, Toaldo, \& Costa, 2018; Hunt, 2015, 2018; Varadarajan, 2010, 2015). In spite of the intrinsic relations between marketing and entrepreneurship - entrepreneurs guide or are guided by markets - very little is said in marketing about entrepreneurs in general. Instead, the literature tends to focus on managerial points of view (Hultman \& Hills, 2011) and studies how marketing occurs in SME's (Bocconcelli et al., 2018; Dzogbenuku \& Keelson, 2019). Because of this focus, the connection between entrepreneurs as sources of innovation is mostly absent. As stated before, in business and in marketing in particular, the entrepreneurial role in influencing decisions about how the company is to position itself to compete in the market and its consequent performance remains outside of the academic discussion. The link between the originator, the entrepreneur, and his creature, the firm's approach to the market, disappears. In this realm, even areas that use the term - Entrepreneurial Marketing and the Marketing/Entrepreneurship Interface, for example do not consider the economic role of the individual entrepreneur and focus, instead on investigating the applications and suggesting adaptations for marketing management techniques when applied to topics such as new ventures, self-employment, family businesses or SME's (see, for example, M. Miles, Gilmore, Harrigan, Lewis, \& Sethna, 2015; and Stokes, 2000). This application of marketing techniques to the entrepreneurial context is well researched, and the gap in the literature lies elsewhere: on the relevance of the entrepreneur to the strategic marketing decisions of the organization. 
Strategic Marketing deals with how organizations must behave in a dynamic world (Hunt, 2015; Varadarajan, 2019), as a consequence, it deals with the possible consequences of innovation (or lack thereof) for these same organizations and society (see section 1 for a detailed treatment). The focus on the consumer was the starting point of research on Market Orientation, research on Entrepreneurial Orientation followed trying to understand how organizations could mimic the behavior of successful entrepreneurs. Further, concepts such as: the structureconduct-performance (SCP); the Institutional Based View (IBV); and the Resource-Based View (RBV) with dynamic capabilities (DC); should be used to support a SM discussion of innovation based on a methodological individualistic view of entrepreneurial action.

In possession of this background, this paper aims to insert in the SM literature the entrepreneurial theory of the firm (Bylund, 2016; Foss \& Klein, 2012) and to shed light to the connections between those two. We suggest a framework in which SM - understood as in Varadarajan (2010) and Hunt (2015), as in section 1, below - and innovation are grounded on the type of entrepreneur that leads the organization. The framework unites previously separated streams of research and is able to guide future research and can therefore help establish a higherlevel comprehension of organizations and innovation as outcomes of entrepreneurial action from a SM perspective. Methodologically, by inserting the individualistic perspective, that considers the individual as the root cause of societal, including organizational, modifications (Rothbard, 1976), the paper takes a complementary approach to the positivistic paradigm and increases the inter and multi-disciplinarity that is needed for the comprehension of complex phenomena studied by the social sciences.

The paper goes as follows: the first part presents how SM deals with innovation and the SM tripod; the second discusses the entrepreneur; the third supports the complementarity among the subjects presenting the framework in which they are connected, as well as a comparative table with related terms used by the areas. Suggestions and limitations conclude.

\section{1 (Strategic) Marketing and Innovation}

Marketing deals with what is relevant for the idealization, production, communication, and distribution of goods or services that (might) be valued by a set of clients - those "(might) be valued" because not all marketing activities will support successful offers; a significant part of these activities is carried out before an offer reaches the market and there are cases in which, although marketing activities were carried out 'properly', a commercially available offer turns out to be unsuccessful. Marketing emerged as a way to better understand markets (Oliveira, 
Moretti, \& Silva, 2017; Shaw, Jones, \& McLean, 2011), and consumer needs in order to create and position value propositions to fulfil consumer demand. Unfortunately, those origins tend to be neglected by contemporary academia, which is focused on short-term impacts and measurement methods. Malhotra's (2018, p. 652) expectation that "more marketing decisions will become automated" perfectly exemplifies that trend (see also Mazzon, 2018).

Other areas, within and outside management, tend to see marketing's main responsibility to help to generate (fast) results through an efficient application of marketing management techniques. This is so pervasive that people, including scholars, misrepresent marketing as its management/tactics (Varadarajan, 2010). Illustratively, less than a third of the Chief Marketing Officers have strategic roles and they tend to be rapidly replaced when shortterm results are non-satisfactory (Whitler \& Morgan, 2017). Marketing's strategic part is neglected by most and it ends up losing influence in strategic decisions (Homburg, Vomberg, Enke, \& Grimm, 2015). However, marketing goes beyond the marketing mix, and tends to work better when dealing with strategic goals (Driest \& Weed, 2014; Germann, Ebbes, \& Grewal, 2015).

At the same time, in academia, the area was impacted by the "naturalization of Social Sciences' (E. W. Miles, 2016) explicit in the (over)focus on measurement (Malhotra, 2018; Mazzon, 2018; Vargo, 2018). Furthermore, the rise of strategy as a standalone literature, of marketing's superspecialized subfields; and the "method over meaning" movement, also contributed to marketing's little strategic relevance in a way that much of the discussion is methodologically or data-driven, not topic-driven (Falcão, Ikeda, \& Campomar, 2017; Hunt, 2002; Reibstein, Day, \& Wind, 2009).

Marketing's strategic orientation remains active in Strategic Marketing (SM), a part of the discipline that deals with concepts and processes that guide the organizations towards the achievement of competitive advantage (Hunt, 2015). This sub-area inherited early marketing's broader agenda and aimed at comprehending markets and indicating how organizations should behave. It has medium-long term impacts in organizations and:

encompasses the study of organizational, inter-organizational and environmental phenomena concerned with (1) the behavior of organizations in the marketplace in their interactions with consumers, customers, competitors and other external constituencies (Varadarajan, 2010, p. 126).

SM and marketing management should not be confounded. SM is connected to organizational strategy (Matos, Matos, Martins, Rosa, \& Bernardon, 2018; Varadarajan, 2010). 
While marketing management, also known as marketing strategy or tactics, is a much narrower field concerning organizational efforts towards the creation, communication, pricing and promotion of goods.

Because SM is inherently about the dynamism of the market, it needs to deal with the way organizations change as time passes. As a consequence, in its very core, SM is directly connected to innovation and its consequences to the performance and even the perpetuation or disappearance of any organization. From a broader perspective, innovation is endogenous and the fundamental characteristic of markets (D'Andrea \& Mazzoni, 2019), the same dynamism that forces entrepreneurs to think about and act in SM is operationalized within companies in their innovative endeavors.

In this realm, it is important to clarify the difference between innovation and invention. Innovations depend upon inventions; but while an invention can be defined as anything new, innovation is the commercial introduction of something new to a given market (Fagerberg, 2006), consisting of changes that have positive impacts to organization's financial figures (Nobrega \& Lima, 2010). From a purer subjectivistic approach, the financial profit is only part of the profit for the entrepreneur, as a consequence, it is theoretically possible for an innovation to occur even in the absence of financial gains for the firm, in case the entrepreneur finds the modification to be psychic profitable. This is, however, hardly the case in commercial ventures. But the central point is that innovations can only be classified as such a posteriori, consequently, it is not possible to 'invest in innovation', but only in 'innovation efforts', which is, fundamentally, what entrepreneurs do (Bylund, 2016). Not all scholars accept the claim that entrepreneurs are essentially innovators. Indeed, the theoretical division between imitative and innovative entrepreneurs illustrates this point (Kirzner, 1973; Packard \& Bylund, 2018). However, we adopt the position that equates the individual economic agent to the act of innovating (Bylund 2016). Regardless of the position, entrepreneurs necessarily rely on changing, on innovation, to put the SM actions that they envision in place.

Innovation efforts are uncertain, which leads scholars and practitioners to look for shortcuts and solutions for the eventual problems that come with the endeavor. Those are efforts to try to further understand and pack processes that lead to successful innovation initiatives, reducing outcome variability. This develops into the various approaches to 'innovation management' which can be divided into two major standpoints: the closed and the open innovation. In closed innovation, the focus is on internal (usually technological) development and its application to new products (Pavitt, 2006). It deeply impacted marketing because firms 
needed to sell something internally developed to restart the innovation effort; since marketing was the responsible for sales to happen, marketing management functions benefited, and strategic marketing suffered. In open innovation, conversely, the market is integrated in the effort (Chesbrough, 2003), marketing regains power and a strategic aspect because understanding the market becomes essential to the development of value propositions that would ideally fill (existing or to be created) market gaps.

The innovation capabilities approach also holds connections with SM. It states that innovation can be found/built all around the organization and sees it as a function of the arrangement of two drivers (technological \& business) of capabilities (development \& operational; and managerial \& transactions, respectively) (Alves, Barbieux, Reichert, TelloGamarra, \& Zawislak, 2017). Business driver innovations tend to be harder to emulate/copy and lead to more lasting competitive advantage.

\subsection{Strategic Orientation and openness to innovation}

The way organizations face the market dynamism can be analyzed from an innovation perspective, either firms are prone or not to innovate. This is not to be confounded with the open and closed innovation paradigms. In those two cases the organizations are open to innovation, but embrace it from different perspectives. The discussion here is another: is an organization willing to embrace change/innovation?

Organizations that embrace innovation will be able or not to cope with market changes; the ones that are averse to it, will either 1. face an (unlikely) static market and continue their success, or 2. face a dynamic market that will expel them. It is important to remember that not all organizations want to change, and some are inpable of doing it (Houston, 1986).

Among innovation-prone organizations, rooted in the 'marketing concept' and in the 'consumer orientation' idea, the concept of Market Orientation arises as the "organizationwide generation of market intelligence pertaining to current and future customer needs, dissemination of the intelligence across departments, and organizationwide responsiveness to it" (Kohli \& Jaworski, 1990, p. 1960), it contrasts with the 'internal orientation' approach (Houston, 1986). For internally oriented organizations, generating intelligence can be insufficient if that is not applied to innovate. Moreover, this narrow view of Market Orientation could be incapable of generating long-lasting competitive advantage because of its adaptive ethos. Generative learning, market-oriented organizations are more capable of generating competitive advantage because they are constantly looking for novelties and finding ways to 
apply them to the production structure (Weerawardena \& O'Cass, 2004), market orientation tends to be relevant when organizations anticipate market trends and act upon them faster than competitors (Kumar et al., 2011). Since it is impossible to know a priori if a market trend is being correctly anticipated, the innovation process is always uncertain.

The SM literature classifies Market Oriented firms into two mutually exclusive types: Market Driven and Market Driving. The first refers to organizations that scan the market for current problems and solutions (an adaptative approach), the second uses the market as a source of insights to try to predict or (maybe) shape the future market (Jaworski, Kohli, \& Sahay, 2000) (a generative approach).

At the same time, some organizations, usually larger ones, while trying to recover more innovate ethos, try to adopt an entrepreneurial/innovative path by embracing an 'Entrepreneurial Orientation (EO)'. This organizational culture aims at transplanting traits of entrepreneurs (decision making practices, ways of approaching the business, etc.), especially related to their eagerness to modify the production structure, into a corporate-setting (Wales, 2016, p. 2).

\subsection{The SM tripod}

SM provides a systematic way to think about markets looking for ways to acquire / develop competitive advantage. An early research stream focused on a given market's competitive structure, the Structure-Conduct-Performance (SCP) (Porter, 1985).

A second tradition is the Resource Based View (RBV) (Barney \& Arikan, 2001), which states that firms are combinations of heterogeneous resources and that the achievement of competitive advantages relies on the firm' skills to arrange their resources most profitably than the average competitor. To generate advantage, resources should be relatively unique, rare, immobile and with inelastic supply (Barney \& Arikan, 2001). Advantages that result from resources can only be sustained across time with continuous adaptation. The Dynamic Capabilities (DC) is complementary to RBV and provides the theoretical explanation to the sources of dynamism, the dynamic innovation capabilities, that make possible for the firms to follow or lead market changes (Teece, 2007).

The Institutional Based View (IBV) (Peng, 2002) is the third leg of the tripod. IBV recognizes that institutions are different among societies, and that they influence all transactions, and by signaling acceptable and supportable choices, help to reduce uncertainty. 
IBV looks at the broader environment that affects businesses considering the rules of the game that govern that specific society; SCM sees the company from a narrower industry perspective; and RBV and DC see the company from the inside. SM literature can gain much from using these three as complementary and necessary for understanding markets and how to generate competitive advantage. Indeed they can be said to form a SM tripod to support analytical thinking about the market in which the venture is inserted. However, a direct relation to the human element is missing in this conversation. The missing point is the figure of the entrepreneur (or the individual acting as the entrepreneur in the particular setting), this individual is the one who will absorb and process the information and will, by employing resources based on subjective valuation, decide how the organizations are to behave in the market. In a certain sense, the entrepreneur is the missing part and empowers the SM tripod analysis by taking it a step further.

\section{Conceptualizing entrepreneurship}

Not all actions are relevant for business, but, in a certain sense, every human action is entrepreneurial. In management, the discussion on entrepreneurship is prolific (Chandra, 2018), as entrepreneurs are seen as important for economic and social development (Powell, 2007) and business schools have been trying to teach entrepreneurship for a long time. However, the individualistic approach that considers the entrepreneur as the fundamental substance of an organization and its SM actions is mostly absent. By uniting this with the market as a process idea $^{1}$, one can further understand the consequences of entrepreneurship to markets. Within the individualistic tradition that deals with entrepreneurship, two complementary theoretical perspectives are noticeable, one that can be represented by Kirzner's (1973) and a second, represented by Foss \& Klein's (2012).

Kirzner (1973) states that entrepreneurs use a special state of attention, 'alertness' to observe, act, and profit upon market opportunities, which, in the most common understanding, are features of the market, objective phenomena, available to anyone in a given market at a given time. Entrepreneurs are more able than other agents to see the arbitrage possibilities and act upon them to collect a profit (Phelan, 2016). For the Kirznerian entrepreneur the future is somehow given, and possibilities are relatively finite. This idea has been disputed by several

\footnotetext{
${ }^{1}$ The market process idea leads to conclusions that are similar to 'creative-destruction' ones (Schumpeter, 1942), but with deep methodological differences, particularly on the endogeneity of innovation (see BoStaph, 2013, p. 421). That cannot be overseen by an analyst of dynamic markets as any student of SM must be.
} 
authors, but Kirzner (2009) himself criticizes the disputes claiming that they misunderstand his ideas.

Foss \& Klein (F\&K) (2012) add the Knightian concept of uncertainty and suggest that entrepreneurs imagine the future and try to transform the reality in that direction. The agent's role is connected to (re)uniting and using resources under his (at least partial) ownership while facing uncertainties derived from the impossibility of possessing perfect knowledge. He uses judgment and resources under his control to decide and acts to achieve the ends that sometimes only he foresees. The entrepreneur guides innovation by applying knowledge via the non-usual deployment of resources, breaking the specialization deadlock, augmenting the roundaboutness of the structure of production while maintaining the connections to that same structure (Bylund, 2016, p. 45). For those entrepreneurs, 'opportunities' are subjective, different people in the same circumstances will act differently because 1. they have different access to means, and 2 . they foresee different ends. In this setting, opportunities depend not only on the market, which provide the grounds for creativity, but mainly on the agent; the possibilities are much greater, limited by his ability to foresee what he aims to achieve and his access to the needed resources.

For the theory of entrepreneurship and the standpoint of SM, those two views are complementary (BoStaph, 2013; Foss \& Klein, 2017; Kirzner, 2009; Phelan, 2016). The Kiznerian entrepreneur acts based on the current market and implies that the future will be similar, trying to explore opportunities by creating firms which are similar to the existing ones, or increasing the productivity of a process; he deals with measurable risk and his actions are incapable of fundamentally changing a market or expanding the Production Possibilities Frontier (PPF). F\&K's entrepreneur, differently, pays special attention to available resources and to his goals. He faces uncertainty and will try to create something new and unique, when successful, his actions expand the PPF and the market itself (see Figure 1b). This approach is similar to Schoemaker \& Day (2018, p. 703).

The Kirznerian entrepreneur works with current possibilities, F\&K's entrepreneur works imagining new possible outcomes.

\section{An integrative framework: SM, innovation and entrepreneurship}

This session suggests an integrated framework as in Kuratko et al. (2015, p. 3) as "a basic conceptual structure (as of ideas)." It is a logical and systematic way to organize phenomena. It serves to identify the relevant variables or components that constitute some subject area of interest, while also bringing order or structure to these components in terms of 
the ways in which they relate to one another." The framework joins the aforementioned ideas showing the complementarity among those scholarships. SM and entrepreneurship, in spite of the different denominations and treatments, hold a lot in common, especially when seen from the underlining perspective provided by innovation.

\subsection{Entrepreneurs and their actions in markets}

Entrepreneurial action leads to the development of Market Driven or Market Driving Organizations. Those, as collective entities, are incapable of acting. They cannot change the structure of production, are unable to innovate, because only people can do so and these same people usually do it within and in the names of the organizations. Innovation is impossible without an actor, a decision maker, an entrepreneur. In order to present the aforementioned framework, the first step is to depart from the Evenly Rotating Economy (ERE), a theoretical situation in which there is no innovation because there is no change in the preference of the individuals and the resources are kept the same (Elias, Chiles, Li, \& D'Andrea, 2020; Rothbard, 2004). From that point on, the entrepreneurs will use their organizations to implement their plans. The first step is for the entrepreneur to decide/choose the organization's strategic orientation. How to innovate? To follow or to lead the unavoidable change? ${ }^{2}$

Figures $1 \mathrm{a}$ and $1 \mathrm{~b}$ represent entrepreneurial actions and the consequent strategic approaches that their organizations use in the marketplace. The squares are Kirznerian opportunities available at each particular time, while the circles are paths that F\&K's entrepreneurs might imagine. In both cases, entrepreneurs would have to direct resources in the pursuit of a given change. Some noteworthy things:

1. Figure 1a is the world within an ERE, in Figure 1b, the ERE assumption has been relaxed (no-ERE);

2. In Figures 1a and 1b. Here are unexplored Kirznerian opportunities inside the current market (inside the current PPF) while the F\&K's unexplored opportunities lay outside of it;

3. As soon as the Kirznerian entrepreneur acts, the market for imitative action reduces, as demonstrated by the comparison between the sizes of the gray rectangle in Figure 1a and the most inner white rectangle in Figure 1b, i.e. there are now fewer chances of

\footnotetext{
${ }^{2}$ Of course, most entrepreneurs do not reason like that, in fact, probably very few of them even bother to think about the theories that try to understand/explain the consequences of their behavior, but it is also a fact that successful companies tend to choose clear paths and tend to be aware of how their business is to be carried out.
} 
being successful only by emulating existing production structures or improving the production methods within the PPF in that particular market;

4. At the same time, as soon as F\&K's entrepreneurs act, the market expands, observe how the light-gray rectangle in Figure $1 \mathrm{~b}$ that represents the PPF's augments when compared to the dark-gray rectangle in Figure 1a Within the no-ERE PPF in Figure 1b, once again, only Kirznerian entrepreneurs will act, F\&K's entrepreneurial 'opportunities' lay outside the current PPF and are represented by the potential (unexplored) market seen in the white outside rectangle;

5. Because of the F\&K's entrepreneurial action in Figure 1b, the size of the market to use a Kirznerian approach increases, there is now a larger market to look for Kirznerian entrepreneurial opportunities, and;

6. In both Figures 1a and 1b, possibilities of F\&K's 'opportunities' emerge outside the PPF and will depend on the judgment and action of F\&K's entrepreneurs. Of course, possible ventures that are closest to the current market setting are the easier ones for those entrepreneurs to imagine and work upon. For example, it is relatively easier to come up with the idea of a mobile phone when landlines are already in place, going from horse-riding to planes is possible, but a much different endeavor.

The phenomenon repeats every time a F\&K's entrepreneur acts. He expands the market, inserts dynamism and provokes change not only for his own organization, but to the whole market (again, he expands the PPF by breaking the specialization deadlock and augmenting the roundaboutness of the production processes in which he is inserted). Concurrently, Kirznerian entrepreneurs will push the market towards equilibrium, reducing the alertness opportunities in a given market every time they act upon one of them. Both kinds of entrepreneurial action are needed and widespread in all properly functioning markets, they represent the dynamism of the market process by 1 . expanding the PPF and making 2. the production processes ever more productive (D’Andrea \& Mazzoni, 2019; Packard \& Bylund, 2018). 
Figure 1: Markets before and after entrepreneurial action

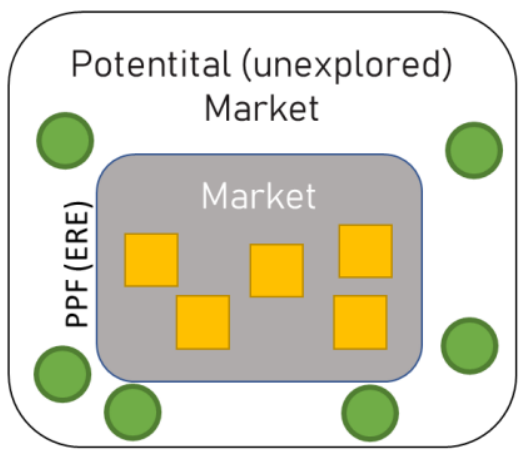

Figure 1a: the Market is in the ERE, opportunities exist, but nobody takes them.

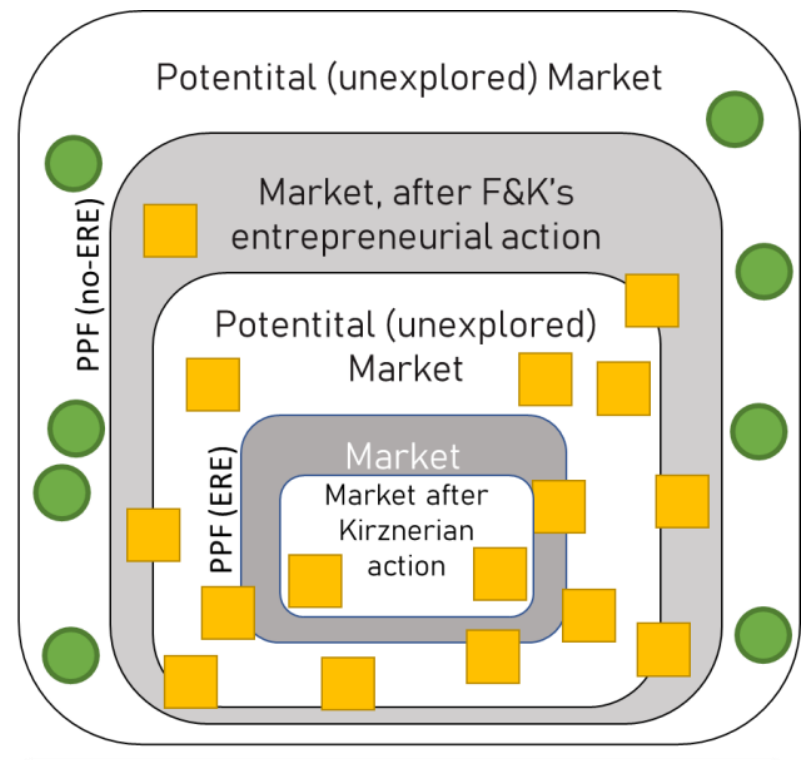

Figure 1b: the ERE assumption has been relaxed. Opportunities have been explored by both Kiznerian and F\&K's entrepreneurs.

Kirznerian Entrepreneurial Opportunities

F\&K Entrepreneurial 'opportunities'

Source: The Authors.

The market after innovation, when the ERE condition has been relaxed, is different in the two entrepreneurial/strategic marketing settings. In the setting put in place by Kirznerian entrepreneurs, without the action of F\&K's entrepreneurs, the innovations will be pulled by the market. There will be a tendency to equilibrium and fewer opportunities to other Kirznerian entrepreneurs, production processes will tend to become more similar, and competition will tend to be driven by productivity and based on prices, competitive advantages will be short term or even non-existent and innovation will be incremental.

On the other hand, F\&K's companies/entrepreneurs will expand the market and, by expanding the PPF via the breaking of the specialization deadlock, will end up offering greater room for of innovation for both types of entrepreneurs (see Figure $1 \mathrm{~b}$ and compare it to the room of opportunities that was present in Figure 1a). At the same time, the inception of marketchanging innovations will push the market to previously unexpected directions, those will provide the promoter entrepreneur with a longer-term competitive advantage due to the deeper changes in the company's settings that make it harder for the competitors to imitate and will give rise to a more disequilibrated market because of the radical innovations. 


\subsection{A SM framework grounded on entrepreneurial action}

Figure 2 presents the framework that unites the ideas on entrepreneurship and Strategic Marketing. The representation shows that, depending on what route the entrepreneur chooses to follow, he will need to pay attention to a different set of strategic variables and a different set of decisions will be the pillars of that firm's struggle towards the achievement of competitive advantage.

If the entrepreneur opts for a Kirznerian kind of endeavor, the company will have to be based on the IBV, the SCP and RBV. This entrepreneur will look at the market and try to cope with the needs and wants of the people in there as best as possible with the resources that he holds at hand, she will be Market Driven, constant and incremental innovations will be pulled by the market more-or-less explicit needs (see the squares in in Figures 1a and 1b). This kind of entrepreneur is guided by causation (Sarasvathy, 2009). The competitive advantage brought by this kind of innovation will tend to be short-lasting because competitors can easily imitate these movements - they are imitator-entrepreneurs in the jargon of Bylund (2016). Kirznerian, entrepreneurs and companies deriving from that kind of persona will be threatened by their Kirznerian competitors and by F\&K's entrepreneurs, and their market changing companies.

Complementary, the quintessential F\&K's entrepreneur looks at the market and arranges resources to compete in a market that does not exist yet and in which he will be the sole ruler until competitors start to imitate his innovations (see the green spots in Figures 1a and 1b). The organization of this entrepreneur not only uses IBV, SCM and RBV but uses entrepreneurial judgment to add the DC to the mix in order to create competitive advantage, instead of causation, it uses effectuation (Sarasvathy, 2009).

F\&K's entrepreneurs pushes the market in the direction that they judge to be the best for their own singular purposes. They drive the market via the implementation of changes that modify the way people and markets behave in a deeper manner - they break the specialization deadlock (Bylund, 2016). In that process they destroy a significant part of the former market that was available for the Kirznerian entrepreneurs (compare Figures 1a and 1b and notice that the market available for Kirznerian entrepreneurship is larger at the ERE, before the introduction of the market-changing innovation brought about by a break in the specialization deadlock). This F\&K's action tends to reduce the number of Kirznerian competitors in that particular marketplace. At the same time, a greater market overall emerges (see the light gray rectangle in Figure 1b), one in which the overall structure of production is longer, and that, consequently, offers more diverse possibilities of action for entrepreneurs. It is the classic 
'creative destruction' mechanism in place but seen from a coherent methodological perspective. The uprising of new, more roundabout industries tends to diminish the possibilities of action for older industrial approaches.

Summing up, F\&K's entrepreneur disequilibrates the markets, and augments the possibilities of action of every single actor, including Kirznerian entrepreneurs, this entrepreneurial strategic orientation, when successful, leads to longer term competitive advantage because it is harder, and takes more time, to emulate/imitate.

The successful Kirzneran entrepreneurial path showed in upper part of the right side of Figure 2 will lead to a market as represented in Figure 1a, more equilibrated, with fewer arbitrage opportunities, and less profitable on average due to increased competition (just like in Packard and Bylund, 2018). The other entrepreneurial path, the one in the bottom of the right side of Figure 2 will lead to a market more similar to the one seen in Figure 1b, with more possibilities of action for both types of entrepreneurs.

Figure 2 - Proposed framework of Strategic Marketing and Entrepreneurship concepts

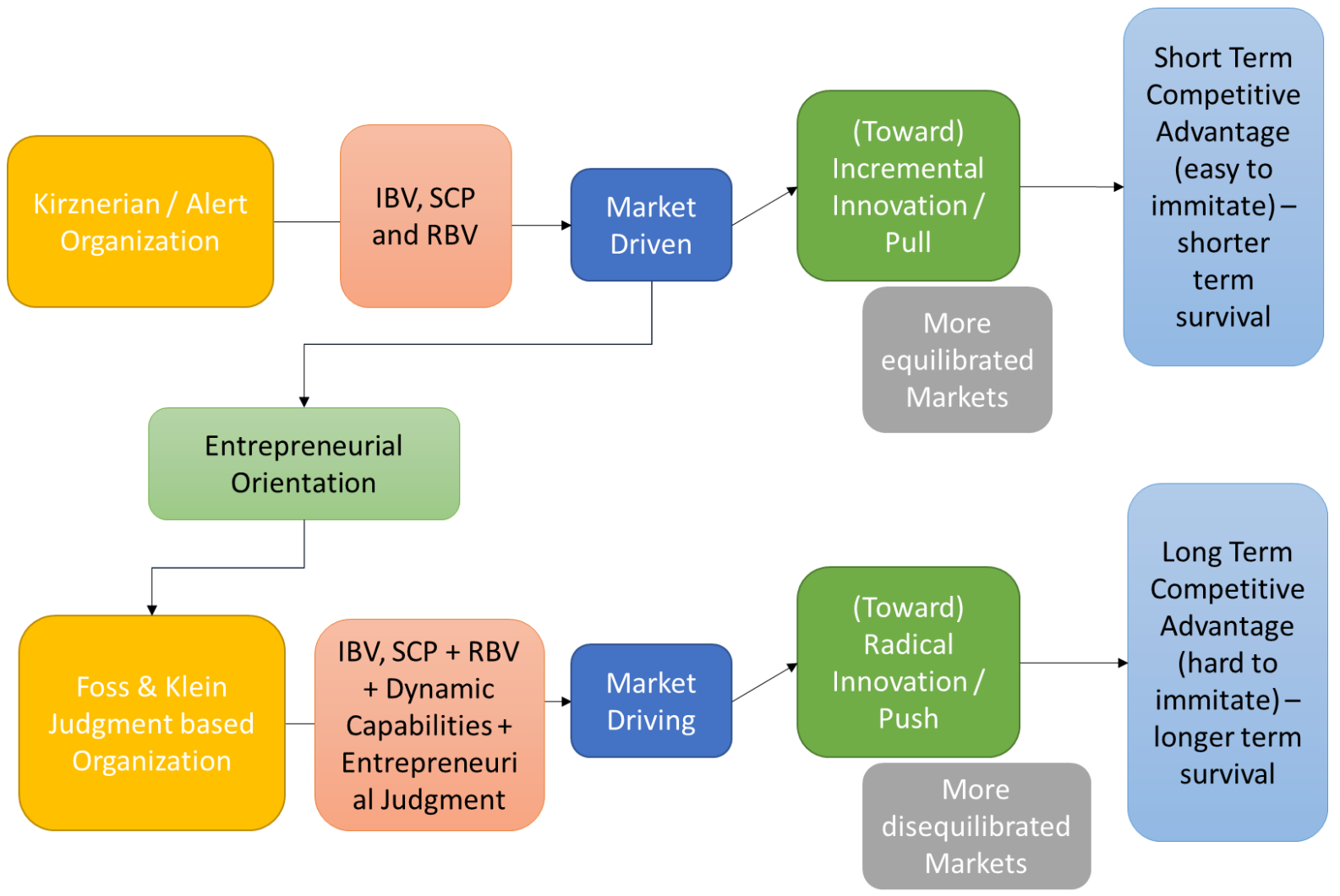

Source: The Authors. 
It is clear that both entrepreneurial/company settings, albeit from different approaches, are capable of generating positive financial results (the volumes will most probably be very different, of course). The main difference lays in their different ability to sustain that financial flow across time based on the innovation that bought competitive advantage, does the innovation provide a shorter or longer period of advantage? Companies aim at keep succeeding, consequently, it would be in their best interest to be Market Driving instead of Market Driven. In that sense, the Entrepreneurial Orientation can be used try to transform a Kirznerian organizational culture into a F\&K's one, that tries to generate longer lasting competitive advantages.

Another relevant thing in the framework is the existence of the Dynamic Capabilities in F\&K's companies. This is their distinctive feature when compared to Kirznerian companies. When adopting this approach: "firms must leverage capabilities to support their distinctive business concept" (Ghauri, Wang, Elg, \& Rosendo-Ríos, 2016, p. 5683). This is important because the Dynamic Capabilities are a feature of the entrepreneurial judgment, for the DC to arise, entrepreneurs (or their agents) will necessarily have to exercise judgment and act upon what they believe has to be changed (D'Andrea \& Luce, 2020; Teece, 2007).

DC can be used to learn from and apply changes to any of the three basic legs of the strategic marketing tripod: entrepreneurs can try to change the Institutional status by playing with political arrangements as in the IBV; they can understand, using the SCP, and work to change the nature of the industry as a whole by changing the arrangement of their own resources; and they can mainly, use the DC to change the internal configurations inside the company, within the realm that the RBV studies. Entrepreneurs that are able to use their creativity and skill to, via their own judgment and the inception of DC, guide the changes in the resources of companies will be more capable of changing the competitive landscape as a whole and will have more chances of being more successful in the longer-term.

Many different discussions in the SM literature deal with those two kinds of entrepreneurial approaches to the markets and their consequent different types of companies' strategic positioning. However, the same SM literature almost never mentions the entrepreneur that gives rise to the particular positioning adopted by the different firms, and thus the connection between the responsible for the fact and the fact itself goes untouched.

To help filling that specific gap and to complement what has been previously discussed, Table 1 is divided in three parts presenting a list of concepts coming and strategic marketing and from entrepreneurship theory, as well as some original contributions. The initial lines in 
the two first parts bring general, widely accepted observations that do not have one single canonical reference which are then followed by chronologically organized references from the specific area of study.

The sources that have been included in Table 1 were suggested by five experts in each of the two fields, all tenured/tenure-track professors working in the United States. These professors were contacted by email and the syllabus of their recent seminars (from 2017 onwards) on the topics consulted. They were asked to point to somewhere between five and ten of the most relevant literature in entrepreneurship and to somewhere between five and ten of the most widely used literature in courses in strategic marketing. Sources that were mentioned on the email responses or appeared in the syllabus more than once were included.

Table 1 provides clarity, facilitates comparison and helps connecting the ideas about the entrepreneurs to the Strategic Marketing researchers to facilitate mutual understanding and pave ways to future collaborations between the fields.

Table 1 - Strategic Marketing and Entrepreneurship concepts that are coincident

Entrepreneur/Company

\begin{tabular}{|c|c|c|}
\hline Entrepreneur/Company & Type I & Type II \\
\hline \multicolumn{3}{|c|}{ Contributions from Strategic Marketing } \\
\hline Related to & Strategy & Innovation \\
\hline Improvement & Continuous and small & Big and sudden \\
\hline Positioning to change & Follow the change & Lead the change \\
\hline Focus on Value & Delivery & Development \\
\hline Managers should & Work to increase productivity & $\begin{array}{l}\text { Work on change (act } \\
\text { entrepreneurially) }\end{array}$ \\
\hline Value proposition & $\begin{array}{l}\text { Almost indistinguishable from } \\
\text { the competition }\end{array}$ & $\begin{array}{l}\text { Substantially different from the } \\
\text { competition }\end{array}$ \\
\hline Learning organization (Senge, 1994) & $\begin{array}{l}\text { Acquire knowledge about the } \\
\text { market }\end{array}$ & $\begin{array}{l}\text { Create knowledge about new } \\
\text { markets }\end{array}$ \\
\hline Competing on (Porter, 1996) & Price-Based & Product-differentiation \\
\hline $\begin{array}{l}\text { Type of innovation (Christensen, } \\
\text { 1997) }\end{array}$ & Sustaining & Disruptive \\
\hline $\begin{array}{l}\text { Move (Lieberman \& Montgomery, } \\
\text { 1998) }\end{array}$ & Late Mover & (Early) First Mover \\
\hline $\begin{array}{l}\text { Market approach } \\
\text { (Srivastava, Shervani, \& Fahey, } \\
\text { 1999) }\end{array}$ & $\begin{array}{l}\text { Exploitation: leveraging } \\
\text { assets/capabilities in } \\
\text { enhancing performance }\end{array}$ & $\begin{array}{l}\text { Exploration: building competitive } \\
\text { advantages }\end{array}$ \\
\hline $\begin{array}{l}\text { Strategic Orientation (Hill \& Wright, } \\
\text { 2000) }\end{array}$ & Market(ing) Orientation & Entrepreneurial Orientation \\
\hline Orientation (Jaworski et al., 2000) & Market Driven & Market Driving \\
\hline $\begin{array}{l}\text { Approach to Value (Mizik \& } \\
\text { Jacobson, 2003) }\end{array}$ & Appropriating value & Creating value \\
\hline $\begin{array}{l}\text { Ocean's Strategy (Kim; Mauborgne, } \\
\text { 2004) }\end{array}$ & Red Ocean & Blue Ocean \\
\hline Business (Maciariello, 2009) & What the business is & What the business ought to be \\
\hline $\begin{array}{l}\text { Type of Learning (Kumar, Jones, } \\
\text { Venkatesan, \& Leone, 2011) }\end{array}$ & Adaptative Learning & Generative Learning \\
\hline
\end{tabular}




\begin{tabular}{|c|c|c|}
\hline $\begin{array}{l}\text { Type of positioning (Thiel \& } \\
\text { Masters, 2014) }\end{array}$ & Zero & One \\
\hline Type of innovation (Hunt, 2015) & Reactive & Proactive \\
\hline $\begin{array}{l}\text { Type of response (Wadhwani \& } \\
\text { Lubinski, 2017) }\end{array}$ & Adaptative response & Creative response \\
\hline \multicolumn{3}{|c|}{ Contributions from Entrepreneurship } \\
\hline Main Author(s) & Kirzner & $\begin{array}{l}\text { Foss \& Klein (with Mises, } \\
\text { Rothbard, Salerno and Bylund) }\end{array}$ \\
\hline $\begin{array}{l}\text { Main characteristic of the } \\
\text { entrepreneur }\end{array}$ & "Alertness" & $\begin{array}{l}\text { Market Creation / Visionary, } \\
\text { Judgment }\end{array}$ \\
\hline Core of action & $\begin{array}{l}\text { Prices in disequilibrium, } \\
\text { arbitrage opportunity }\end{array}$ & Acting under Knightian uncertainty \\
\hline $\begin{array}{l}\text { Where doubts come from? (Knight, } \\
\text { 1921) }\end{array}$ & Risk & Uncertainty \\
\hline $\begin{array}{l}\text { Degree of technological Innovation } \\
\text { (Schumpeter, 1942) }\end{array}$ & Incremental & Radical \\
\hline Market change (Lachmann, 1977) & Equilibrating & Disequilibrating \\
\hline $\begin{array}{l}\text { Type of Economic Agent (Lachmann, } \\
\text { 1986) }\end{array}$ & $\begin{array}{l}\text { Arbitrator (sometimes } \\
\text { Speculator) }\end{array}$ & Innovator (sometimes Speculator) \\
\hline $\begin{array}{l}\text { Type of Entrepreneurship (Cheah, } \\
\text { 1990) }\end{array}$ & Austrian & Schumpeterian \\
\hline View (Holcombe, 1999) & Equilibrium & Invisible hand \\
\hline Market for goods (Barbieri, 2001) & Common & Speculative \\
\hline $\begin{array}{l}\text { Production Function (Lundvall \& } \\
\text { Borrás, 2005) }\end{array}$ & $\begin{array}{l}\text { (Almost) given production } \\
\text { function }\end{array}$ & $\begin{array}{l}\text { Impossible to pre-establish } \\
\text { production function }\end{array}$ \\
\hline $\begin{array}{l}\text { Entrepreneurial Action (Alvarez \& } \\
\text { Barney, 2007) }\end{array}$ & Discovery & Creation \\
\hline $\begin{array}{l}\text { Economic Efficiency (Huerta de } \\
\text { Soto, 2009) }\end{array}$ & Static Efficiency & Dynamic Efficiency \\
\hline $\begin{array}{l}\text { Activity (Wiklund, Davidsson, } \\
\text { Audretsch, \& Karlsson, 2011) }\end{array}$ & $\begin{array}{l}\text { Pre-existent kind of Economic } \\
\text { Activity }\end{array}$ & New Economic Activity \\
\hline $\begin{array}{l}\text { Effects of Entrepreneurship (Keyhani } \\
\text { \& Lévesque, 2016) }\end{array}$ & Equilibrating & Disequilibrating \\
\hline Capital arrangement (Bylund, 2016) & Almost the same & (usually) Completely New \\
\hline Type of entrepreneur (Bylund, 2016) & $\begin{array}{l}\text { Imitator-entrepreneur, } \\
\text { augments the competition } \\
\text { working within a pre- } \\
\text { established production } \\
\text { function }\end{array}$ & $\begin{array}{l}\text { Entrepreneur, breaks the } \\
\text { specialization deadlock and } \\
\text { establishes a new method of } \\
\text { production and a new step in the } \\
\text { production process }\end{array}$ \\
\hline Perspective (Klein, 2017) & Opportunity / Discovery & Judgement-based \\
\hline $\begin{array}{l}\text { Nature of action (Packard \& Bylund, } \\
\text { 2018) }\end{array}$ & $\begin{array}{l}\text { Equilibrating } \\
\text { Entrepreneurship }\end{array}$ & Disequilibrating Entrepreneurship \\
\hline \multicolumn{3}{|c|}{ Original Contributions } \\
\hline $\begin{array}{l}\text { Strategic Analysis methodological } \\
\text { tools }\end{array}$ & SCP, IBV, RBV & $\begin{array}{l}\text { SCP, IBV, RBV \& DC } \\
\text { (entrepreneurial judgment lead) }\end{array}$ \\
\hline Possibilities of action & $\begin{array}{l}\text { Reduced for Kirznerian } \\
\text { entrepreneurs in that market }\end{array}$ & Augments for both types \\
\hline Relationship with public sector & $\begin{array}{l}\text { Depends on legal defense to } \\
\text { achieve long term competitive } \\
\text { advantage }\end{array}$ & $\begin{array}{l}\text { Does not need protective } \\
\text { intervention, will probably face } \\
\text { regulatory uncertainty }\end{array}$ \\
\hline Type of entrepreneur and PPF & $\begin{array}{l}\text { Entrepreneur works within the } \\
\text { PPF }\end{array}$ & $\begin{array}{l}\text { Promoter-Entrepreneur, expands } \\
\text { the PPF }\end{array}$ \\
\hline
\end{tabular}

Source: The authors. 
Table 1 shows the overlapping coherence that underlies the studies in SM and entrepreneurship when one adopts the point of view of innovation. With that in hand, researchers in SM can diversify their field of study by paying more attention to the entrepreneurs as responsible for the strategic marketing initiatives and positioning of firms However, this implies some methodological change, since researchers will have to adapt their approaches to a methodological individualism focus in support of the previously existent SM tools and techniques that IBV, SCM, and RBV+DC already provide.

\section{Conclusions and future research}

Day \& Wensley (1983) state that the fields of strategic marketing and strategy are very close, while Davidsson (2016) points that there has been a quite orchestrated overlap between the researchers in entrepreneurship and strategy. This work stands with those scholars. It also contributes to recent developments (Schoemaker \& Day, 2018) that recognize the importance of the human factor to the innovation approach under conditions of uncertainty.

Moreover, by adopting the entrepreneurial theory of the firm (Bylund, 2016; Foss \& Klein, 2012), grounded in solid economic theory, the work empowers Strategic Marketing theory by overcoming the problem of a lack of a theory of the market in marketing, as pointed by Vargo (2018, p. 732).

There is a need for a deeper understanding of the role of marketing, and Strategic Marketing in particular, in innovation. The entrepreneurial approach is a good way of dealing with that and opening paths to discussion. This paper shows that innovation is inherent in marketing; it is especially important for its strategic part. Marketing's very core is about doing things in order to serve a market with a product and profit from it, the underline cause of innovation is inherently the same. Innovations exist because people foresee better possibilities of futures for them and organize firms to develop solutions and offer products to markets that they imagine will generate a profitable demand. Some studies in entrepreneurship label that 'empathic accuracy' and many connections between that line of research and SM exist and are yet to be explored (see, for instance, Mcmullen, 2015, p. 670).

Because of the market dynamism, organizations as a whole must have innovation as an underlying necessity and Strategic Marketing has the obligation to deal with that constant need to change. At the same time, entrepreneurship is regarded as more than simply a singular act or activity; it must be seen an overall strategic posture (Wales, 2016, p. 2) that will guide the firm throughout its lifecycle. Again, the connections exist and could be explored for gains in SM. 
A consequence of this paper's analysis is that a part of the studies on strategy is actually a subset of the studies on innovation, as some authors already consider (Alvarez, 2003; Minniti, 2003). In addition, the existence of chairs in business schools that deal with strategy, innovation and entrepreneurship at the same time, supports the overall approach of this essay.

Moreover, our approach makes it possible to state that, if analyzed from a strictly theoretical point of view, Kirznerian entrepreneurs can be considered a subset of F\&K's approach. However, an approach considering them as different facilitates the discussion and helps bridging the literatures by pedagogically showing their points of contact and their differences, thus opening new avenues to research.

As for future developments, there is a need to better understand how entrepreneurs can lead innovation in both small and large organizational structures while coping with the different constraints and incentives inherent to those settings (Barney, Foss, \& Lyngsie, 2018). In that sense, in larger organizational settings, managers should have the power and responsibilities of acting entrepreneurially, if this is the goal of the firm, it is advisable to appoint to those positions people that hold entrepreneurial characteristics (Sarasvathy, 2009) that will fit to the strategic approach the company wants to pursue. It is also necessary to understand which would be the best set of incentives and intra-organizational settings in which such a behavior could flourish. Decision makers above those actors have to be aware of the possibilities of failure inherent to innovation efforts. Something has started to be done (D'Andrea \& Luce, 2020), but many more studies are needed to try to further understand the connections between the judgment-based entrepreneurship and the dynamic capabilities literature. This line of research would be useful to discuss how entrepreneurial judgment can help shaping the company's DCs and consequently to further understand how [proxy]entrepreneurs will influence the innovation efforts in every organization. It is still to be understood if/how entrepreneurs are able to transfer their strategic marketing inclinations into the firms they lead and how that happens in different organizational settings. By better understanding that, researchers can end up becoming more capable of understanding and influencing the creation of competitive advantage, including facilitating the understanding of how to sustain an Entrepreneurial Orientation within the firm, even after its growth and (necessary) bureaucratization.

Empirical studies in smaller firms, in which the owner-entrepreneur is more directly in charge of the strategic marketing actions, will help addressing the gaps that have been presented. By observing and measuring how entrepreneurs, in their small ventures, decide and implement strategic marketing decisions will surely advance the disciplinary knowledge. A 
possibility would be to investigate how cognitive traits of the entrepreneur are linked to the creation of dynamic capabilities of sensing and sizing, these two capabilities can be connected to strategic marketing decisions and positioning.

Also from an empirical point of view, using panels would be especially advisable to test the suggested framework, researchers could try to follow the initiatives to transform a Market Driven company into a Market Driving one based on entrepreneurial judgment lead DCs. Also, following actors in ventures and understanding how these companies behave and transform over a long time time, checking whether or not they end up following the entrepreneur's initial Strategic Marketing approach, would contribute to the understanding of the firms, entrepreneurship and innovation as a whole and how those processes develop in organizational settings.

For pedagogical reasons it would be important to come up with examples of both kinds of entrepreneurs explicating in which institutional setting they are more likely to emerge. Theoretical foundations suggest that the Kirznerian entrepreneur would be more easily seen in less dynamic environments, in which resources are not abundant and the cultural background would be less prone to dynamism; underdeveloped and poor nations, as well as the less technological sectors of the economy come to mind. On the other hand, F\&K's entrepreneur would be seen more often where resources (including financial) are abundant, and more diverse, and where the roundaboutness of production is greater, in which capital is available for unusual experiments and uncertainty. Maybe that is why most breakthrough innovative companies tend to emerge in very specific and narrow geographical areas. Those theoretical conclusions should be further investigated by empirical examination.

Furthermore, it would be advisable to use the already known constructs of DC and connect them to the ones related to the F\&K's entrepreneur, by doing so it would be possible to uncover more connections between the two streams and further understand how those influence each other in real life environments.

Another thing that remains to be explored is the connection between the four sources of innovation and the influence exercised by [proxy]entrepreneurs in each of them. Because of path dependencies, it would look like the harder sources (products and processes) would be less influenceable, while the softer ones (management and marketing) could be more easily changed because of their (at least in theory) smaller dependence on physical assets and financial capital. At the same time, however, cultural changes might be very difficult to implement. 
Another point of attention might be how to connect Strategic Management underlying need for innovation to the classic four areas of an organization (operations, finance, people and marketing) and how every possible source of innovation might influence each of those four areas. Exploring this specific idea would lead to a more comprehensive understanding of the organizations as a whole, since it would connect some of the most profound understandings of organizations to the ways in which entrepreneurs are able to keep their success across the dynamic market changes that occur over a long time.

In conclusion, this essay showed that there is much overlap between two seemingly distinct scholarships, Strategic Marketing and entrepreneurship. It became clear that the economic theory about the individual entrepreneur has much to collaborate with the understanding of firms in the market and their constant search for innovation and consequent competitive advantage. It is the role of Strategic Marketing researchers to overcome the "not invented here" complex and use the knowledge coming from the studies in entrepreneurship that use methodological individualism to foster their comprehension of the phenomena under their scrutiny and to further understand how firms, outcomes of entrepreneurial action, are shaped by and shape markets.

\section{References}

Alvarez, S. A. (2003). Resources and Hierarchies: Intersections between Entrepreneurship and Strategy. In Handbook of Entrepreneurship Research (pp. 247-263). New York: Springer-Verlag. https://doi.org/10.1007/0-387-24519-7_11

Alvarez, S. A., \& Barney, J. B. (2007). The Entrepreneurial Theory of the Firm. Journal of Management Studies, 44(7), 1057-1063. https://doi.org/10.1111/j.1467-6486.2007.00721.x

Alves, A. C., Barbieux, D., Reichert, F. M., Tello-Gamarra, J., \& Zawislak, P. A. (2017). Innovation and Dynamic Capabilities of the Firm: Defining an Assessment Model. Revista de Administração de Empresas, 57(3), 232-244. https://doi.org/10.1590/s0034759020170304

Barbieri, F. (2001). O processo de mercado na escola austríaca moderna. Biblioteca Digital de Teses e Dissertações da Universidade de São Paulo, São Paulo. https://doi.org/10.11606/D.12.2001.tde-20102001-144955

Barney, J. B., \& Arikan, A. M. (2001). The Resource-based View: Origins and Implications. In M. A. Hitt, R. E. Freeman, \& J. S. Harrison (Eds.), The Blackwell Handbook of Strategic Management (pp. 124-188). Oxford, UK: Blackwell Publishers Inc. https://doi.org/10.1111/b.9780631218616.2006.x 
Barney, J. B., Foss, N. J., \& Lyngsie, J. (2018). The role of senior management in opportunity formation: Direct involvement or reactive selection? Strategic Management Journal, 39(5), 1325-1349. https://doi.org/10.1002/smj.2768

Bocconcelli, R., Cioppi, M., Fortezza, F., Francioni, B., Pagano, A., Savelli, E., \& Splendiani, S. (2018). SMEs and Marketing: A Systematic Literature Review. International Journal of Management Reviews, 20(2), 227-254. https://doi.org/10.1111/ijmr.12128

BoStaph, S. (2013). Driving the market process: "Alertness" versus Innovation and Creative Destruction. Quarterly Journal of Austrian Economics, 16(4), 421-458.

Bylund, P. L. (2016). The problem of production: a new theory of the firm. Routledge.

Chandra, Y. (2018). Mapping the evolution of entrepreneurship as a field of research (19902013): A scientometric analysis. PLOS ONE, 13(1), e0190228.

https://doi.org/10.1371/journal.pone.0190228

Cheah, H.-B. (1990). Schumpeterian and Austrian entrepreneurship: Unity within duality. Journal of Business Venturing, 5(6), 341-347. https://doi.org/10.1016/08839026(90)90010-Q

Chesbrough, H. (2003). Open innovation. Boston: Harvard Business School Press.

Christensen, C. M. (1997). The innovator's dilemma. Cambridge, Mass., USA: Harvard Business School Press.

D'Andrea, F. A. M. C., \& Luce, F. B. (2020). Entrepreneurs as real sources of Innovation A Strategic Marketing Perspective (Working Paper: Universidade Federal do Rio Grande do Sul).

D’Andrea, F. A. M. C., \& Mazzoni, J. F. (2019). For a less dramatic creative destruction. MISES: Interdisciplinary Journal of Philosophy, Law and Economics, 7(3). https://doi.org/10.30800/mises.2019.v7.1245

Davidsson, P. (2016). The field of entrepreneurship research: Some significant developments. In D. G. P. de Bögenhold, Dieter; Bonnet, Jean; Dejardin, Marcus; Lema (Ed.), Contemporary Entrepreneurship: Multidisciplinary Perspectives on Innovation and Growth (pp. 17-28). Cham: Springer. https://doi.org/10.1007/978-3-319-28134-6_2

Day, G. S., \& Wensley, R. (1983). Marketing Theory with a Strategic Orientation. Journal of Marketing, 47(4), 79. https://doi.org/10.2307/1251401

Driest, F. Van den, \& Weed, K. (2014). The ultimate marketing machine. Harvard Business Review, 92, 54-63.

Dzogbenuku, R. K., \& Keelson, S. A. (2019). Marketing and entrepreneurial success in emerging markets: the nexus. Asia Pacific Journal of Innovation and Entrepreneurship, 13(2), 168-187. https://doi.org/10.1108/APJIE-12-2018-0072 
Elias, S. R. S. T. A., Chiles, T. H., Li, Q., \& D’Andrea, F. A. M. C. (2020). Austrian Economics and Organizational Entrepreneurship: A Typology. Quarterly Journal of Austrian Economics, 23(3-4). https://doi.org/10.35297/qjae.010073

Fagerberg, J. (2006). Innovation: a guide to the literature. In J. Fagerberg, D. C. Mowery, \& R. R. Nelson (Eds.), The Oxford handbook of innovation (pp. 1-26). Oxford University Press.

Falcão, R. F., Ikeda, A. A., \& Campomar, M. C. (2017). Is Marketing Losing its Identity? A Bibliometric Review. Revista Brasileira de Marketing, 16(02), 154-167. https://doi.org/10.5585/remark.v16i2.3450

Finoti, L. L., Didonet, S. R., Toaldo, A. M. M., \& Costa, J. C. N. da. (2018). A Influência da Inovatividade no Processo de Estratégia de Marketing e o Impacto sobre o Desempenho Organizacional: Evidências do Setor TIC. Revista Brasileira de Marketing, 17(02), 166186. https://doi.org/10.5585/remark.v17i2.3521

Foss, N. J., \& Klein, P. G. (2012). Organizing entrepreneurial judgment : a new approach to the firm. Cambridge University Press.

Foss, N. J., \& Klein, P. G. (2017). Entrepreneurial Discovery or Creation? In Search of the Middle Ground. Academy of Management Review, 42(4), 733-736. https://doi.org/10.5465/amr.2016.0046

Germann, F., Ebbes, P., \& Grewal, R. (2015). The Chief Marketing Officer Matters! Journal of Marketing, 79(3), 1-22. https://doi.org/10.1509/jm.14.0244

Ghauri, P., Wang, F., Elg, U., \& Rosendo-Ríos, V. (2016). Market driving strategies: Beyond localization. Journal of Business Research, 69(12), 5682-5693.

https://doi.org/10.1016/J.JBUSRES.2016.04.107

Hill, J., \& Wright, L. T. (2000). Defining the Scope of Entrepreneurial MArketing: A Qualitative Approach. Journal of Enterprising Culture, 08(01), 23-46. https://doi.org/10.1142/S0218495800000036

Holcombe, R. G. (1999). Equilibrium Versus the Invisible Hand. The Review of Austrian Economics, 12(2), 227-243. https://doi.org/10.1023/A:1007820310502

Homburg, C., Vomberg, A., Enke, M., \& Grimm, P. H. (2015). The loss of the marketing department's influence: is it really happening? And why worry? Journal of the Academy of Marketing Science, 43(1), 1-13. https://doi.org/10.1007/s11747-014-0416-3

Houston, F. S. (1986). The Marketing Concept: What it is and What it is Not. Journal of Marketing, 50(2), 81-87. https://doi.org/10.1177/002224298605000207

Huerta de Soto, J. (2009). The theory of dynamic efficiency. Routledge. 
Hultman, C. M., \& Hills, G. E. (2011). Influence from entrepreneurship in marketing theory. Journal of Research in Marketing and Entrepreneurship, 13(2), 120-125. https://doi.org/10.1108/14715201111176408

Hunt, S. D. (2002). Foundations of marketing theory: toward a general theory of marketing. Armonk N.Y.: M.E. Sharpe.

Hunt, S. D. (2015). The theoretical foundations of strategic marketing and marketing strategy: foundational premises, R-A theory, three fundamental strategies, and societal welfare. $A M S$ Review, 5(3-4), 61-77. https://doi.org/10.1007/s13162-015-0069-5

Hunt, S. D. (2018). Advancing marketing strategy in the marketing discipline and beyond: from promise, to neglect, to prominence, to fragment (to promise?). Journal of Marketing Management, 34(1-2), 16-51. https://doi.org/10.1080/0267257X.2017.1326973

Jaworski, B., Kohli, A. K., \& Sahay, A. (2000). Market-Driven Versus Driving Markets. Journal of the Academy of Marketing Science, 28(1), 45-54. https://doi.org/10.1177/0092070300281005

Keyhani, M., \& Lévesque, M. (2016). The Equilibrating and Disequilibrating Effects of Entrepreneurship: Revisiting the Central Premises. Strategic Entrepreneurship Journal, 10(1), 65-88. https://doi.org/10.1002/sej.1210

Kim, W. C., \& Mauborgne, R. (2004). Blue Ocean Strategy. Harvard Business Review, (October). Retrieved from https://hbr.org/2004/10/blue-ocean-strategy

Kirzner, I. M. (1973). Competition and entrepreneurship. University of Chicago Press.

Kirzner, I. M. (2009). The alert and creative entrepreneur: a clarification. Small Business Economics, 32(2), 145-152. https://doi.org/10.1007/s11187-008-9153-7

Klein, P. G. (2017). An Austrian Perspective on Firms and Markets: My Contributions to Entrepreneurship Theory. In D. B. Audretsch \& E. E. Lehmann (Eds.), The Routledge Companion to the Makers of Modern Entrepreneurship (pp. 146-153). New York, NY, USA: Routledge.

Knight, F. H. (1921). Risk, Uncertainty, and Profit. Boston \& New York: Houghton Mifflin Company.

Kohli, A. K., \& Jaworski, B. J. (1990). Market Orientation: The Construct, Research Propositions, and Managerial Implications. Journal of Marketing, 54(2), 1. https://doi.org/10.2307/1251866

Kumar, V., Jones, E., Venkatesan, R., \& Leone, R. P. (2011). Is Market Orientation a Source of Sustainable Competitive Advantage or Simply the Cost of Competing? Journal of Marketing, 75(1), 16-30. https://doi.org/10.1509/jm.75.1.16

Lachmann, L. M. (1977). Ludwig von Mises and the market process. In Capital, Expectations and the Market Process (pp. 181-193). Kansas City: Sheed, Andrews and McMeel.

Lachmann, L. M. (1986). The Market as an Economic Process. New York: Oxford: Basil 
Blackwell.

Lieberman, M. B., \& Montgomery, D. B. (1998). First-mover (dis)advantages: retrospective and link with the resource-based view. Strategic Management Journal, 19(12), 1111-1125. https://doi.org/10.1002/(SICI)1097-0266(1998120)19:12<1111::AID-SMJ21>3.0.CO;2-W

Lundvall, B.-Å., \& Borrás, S. (2005). Science, technology, and innovation policy. In Oxford handbook of innovation (pp. 599-631). Oxford University Press.

Maciariello, J. (2009). Marketing and innovation in the Drucker Management System. Journal of the Academy of Marketing Science, 37(1), 35-43. https://doi.org/10.1007/s11747-008-0098-9

Malhotra, N. K. (2018). Marketing Research: Current State and Next Steps. Revista Brasileira de Marketing, 17(05), 647-665. https://doi.org/10.5585/bjm.v17i5.4172

Matos, C., Matos, C. A. de, Martins, F. E., Rosa, M. B. da, \& Bernardon, R. (2018). Os Efeitos do Alinhamento entre Práticas de Marketing e Estratégia de Negócios no Desempenho das Empresas. Revista Brasileira de Marketing, 17(6), 849-865. https://doi.org/10.5585/remark.v17i6.3774

Mazzon, J. A. (2018). Using the Methodological Association Matrix in Marketing Studies. Revista Brasileira de Marketing, 17(05), 747-770. https://doi.org/10.5585/bjm.v17i5.4175

Mcmullen, J. S. (2015). Entrepreneurial judgment as empathic accuracy: a sequential decision-making approach to entrepreneurial action. Journal of Institutional Economics, 11(3), 651-681. https://doi.org/10.1017/S1744137413000386

Miles, E. W. (2016). Critical Juncture III: The 1959 Foundation Reports - Throwing Out the Baby with the Bath Water? In The Past, Present, and Future of the Business School (pp. 65-76). Cham: Springer International Publishing. https://doi.org/10.1007/978-3-31933639-8_8

Miles, M., Gilmore, A., Harrigan, P., Lewis, G., \& Sethna, Z. (2015). Exploring entrepreneurial marketing. Journal of Strategic Marketing, 23(2), 94-111. https://doi.org/10.1080/0965254X.2014.914069

Minniti, M. (2003). Entrepreneurship Studies: A Stocktaking (pp. 9-37). https://doi.org/10.1016/S1529-2134(03)06002-2

Mizik, N., \& Jacobson, R. (2003). Trading off between Value Creation and Value Appropriation: The Financial Implications of Shifts in Strategic Emphasis. Journal of Marketing, 67(1), 63-76. https://doi.org/10.1509/jmkg.67.1.63.18595

Nobrega, C., \& Lima, A. R. de. (2010). INNOVATRIX: inovação para não gênios. Rio de Janeiro, RJ, Brasil: Agir.

Oliveira, S. L. I. de, Moretti, S. L. A., \& Silva, L. A. (2017). Os Primeiros Estudos em Marketing: A Influência da Filosofia e das Ciências nos Primeiros Estudos em Marketing Uma Análise da Obra Marketing Problems de Melvin T. Copeland. Revista Brasileira de Marketing, 16(04), 502-519. https://doi.org/10.5585/remark.v16i4.3508 
Packard, M. D., \& Bylund, P. L. (2018). On the relationship between inequality and entrepreneurship. Strategic Entrepreneurship Journal, 12(1), 3-22. https://doi.org/10.1002/sej.1270

Pavitt, K. (2006). Innovation Processes. In J. Fagerberg, D. C. Mowery, \& R. R. Nelson (Eds.), The Oxford Handbook of Innovation. Oxford University Press. https://doi.org/10.1093/oxfordhb/9780199286805.003.0004

Peng, M. W. (2002). Towards an Institution-Based View of Business Strategy. Asia Pacific Journal of Management, 19(2/3), 251-267. https://doi.org/10.1023/A:1016291702714

Phelan, S. E. (2016). Austrian theories of entrepreneurship: Insights from complexity theory. The Review of Austrian Economics, 29(3), 277-297. https://doi.org/10.1007/s11138-0150302-3

Porter, M. E. (1985). The Competitive Advantage: Creating and Sustaining Superior Performance. Los Angeles, CA, USA: The Free Press.

Porter, M. E. (1996). What is strategy? Harvard Business Review, (Nov-Dez), 61-78.

Powell, B. (2007). Making Poor Nations Rich: Entrepreneurship and the Process of Economic Development (Stanford E). Boston, Massachussets: Stanford University Press.

Reibstein, D. J., Day, G. S., \& Wind, J. (2009). Guest Editorial: Is Marketing Academia Losing Its Way? Journal of Marketing, 73(4), 1-3. https://doi.org/10.1509/jmkg.73.4.1

Rothbard, M. N. (1976). Praxeology: The methodology of Austrian economics. In The Foundations of Modern Austrian Economics (pp. 19-39).

Rothbard, M. N. (2004). Man, Economy, and State A Treatise on Economic Principles with Power and Market Government and the Economy (Second). Auburn, Alabama, USA: Ludwig von Mises Institute.

Sarasvathy, S. D. (2009). Effectuation : elements of entrepreneurial expertise. Elgar.

Schoemaker, P. J. H., \& Day, G. S. (2018). Strategic Actions in the Face of Uncertainty. Revista Brasileira de Marketing, 17(05), 700-729. https://doi.org/10.5585/bjm.v17i5.4178

Schumpeter, J. A. (1942). Capitalism, Socialism and Democracy. New York, NY, USA: Harper and Row.

Senge, P. (1994). The Fifth Discipline: The art and practice of the learning organization. Random House.

Shaw, E. H., Jones, D. G. B., \& McLean, P. A. (2011). The Early Schools of Marketing Thought. In P. Maclaran, M. Saren, B. Stern, \& M. Tadajewski (Eds.), The SAGE Handbook of Marketing Theory (pp. 27-41). London, UK: SAGE Publications Ltd. https://doi.org/10.4135/9781446222454.n2

Srivastava, R. K., Shervani, T. A., \& Fahey, L. (1999). Marketing, Business Processes, and Shareholder Value: An Organizationally Embedded View of Marketing Activities and the Discipline of Marketing. Journal of Marketing, 63(4_supp11), 168-179. https://doi.org/10.1177/00222429990634s116 
Stokes, D. (2000). Putting Entrepreneurship into Marketing: The Processes of Entrepreneurial Marketing. Journal of Research in Marketing and Entrepreneurship, 2(1), 1-16. https://doi.org/10.1108/14715200080001536

Teece, D. J. (2007). Explicating dynamic capabilities: the nature and microfoundations of (sustainable) enterprise performance. Strategic Management Journal, 28, 1319-1350. https://doi.org/https://doi.org/10.1002/smj.640

Thiel, P. A., \& Masters, B. (2014). Zero to one: Notes on startups, or how to build the future. Broadway Business.

Varadarajan, R. (2010). Strategic marketing and marketing strategy: Domain, definition, fundamental issues and foundational premises. Journal of the Academy of Marketing Science, 38(2), 119-140. https://doi.org/10.1007/s11747-009-0176-7

Varadarajan, R. (2015). Strategic marketing, marketing strategy and market strategy. AMS Review, 5(3-4), 78-90. https://doi.org/10.1007/s13162-015-0073-9

Varadarajan, R. (2019). Theoretical underpinnings of research in strategic marketing: a commentary. Journal of the Academy of Marketing Science, 47(1), 30-36. https://doi.org/10.1007/s11747-018-0612-7

Vargo, S. L. (2018). Marketing Relevance Through Market Theory. Revista Brasileira de Marketing, 17(05), 730-746. https://doi.org/10.5585/bjm.v17i5.4177

Wadhwani, R. D., \& Lubinski, C. (2017). Reinventing Entrepreneurial History. Business History Review, 91(04), 767-799. https://doi.org/10.1017/S0007680517001374

Wales, W. J. (2016). Entrepreneurial orientation: A review and synthesis of promising research directions. International Small Business Journal: Researching Entrepreneurship, 34(1), 3-15. https://doi.org/10.1177/0266242615613840

Weerawardena, J., \& O'Cass, A. (2004). Exploring the characteristics of the market-driven firms and antecedents to sustained competitive advantage. Industrial Marketing Management, 33(5), 419-428. https://doi.org/10.1016/J.INDMARMAN.2003.07.002

Whitler, K. A., \& Morgan, N. (2017). Why CMOs never last and what to do about it. Harvard Business Review, 95(4), 47+-.

Wiklund, J., Davidsson, P., Audretsch, D. B., \& Karlsson, C. (2011). The Future of Entrepreneurship Research. Entrepreneurship Theory and Practice, 35(1), 1-9. https://doi.org/10.1111/j.1540-6520.2010.00420.x 


\title{
UMA PERSPECTIVA DE MARKETING ESTRATÉGICO SOBRE EMPREENDEDORES E INOVAÇÃO
}

\author{
Fernando Antonio Monteiro Christoph D'Andrea \\ Doutorando em Adminitração / Marketing \\ Escola de Administração - Universidade Federal do Rio Grande do Sul EA-URGRS \\ Porto Alegre, RS, Brasil \\ dodandrea@gmail.com \\ Fernando Bins Luce \\ Professor Titular \\ Escola de Administração - Universidade Federal do Rio Grande do Sul EA-URGRS \\ Porto Alegre, RS, Brasil \\ fernando.luce@ufrgs.br
}

Objetivo: Apresentar as profundas e inexploradas conexões entre as teorias em Marketing Estratégico e Empreendedorismo usando a inovação como fenômeno basilar.

Método: Este é um artigo conceitual que discute as literaturas mencionadas anteriormente e demonstra que a inovação pode ser vista como conexão entre o individualismo metodológico da teoria empreendedorial da firma e a literatura em marketing estratégico. A literatura fundamental em empreendedorismo deste ponto de vista, bem como as referências mais relevantes em marketing estratégico foram comparadas.

Resultados Principais: Mais do que expor tais conexões, o trabalho traz dois resultados objetivos: um framework que conecta desenvolvimentos teóricos previamente vistos nas duas literaturas e; uma tabela comparativa com os conceitos teóricos e contribuições originais. Ambos oferecem caminhos para o desenvolvimento de pesquisas teóricas e/ou empíricas.

Contribuições teóricas e metodológicas: $\mathrm{O}$ trabalho elucida a complementariedade entre as literaturas, melhorando a interdisciplinaridade e dando um primeiro passo para reinserir o individualismo metodológico como uma perspectiva metodológica válida no marketing e no marketing estratégico. Mais especificamente, isto se dá por posicionar o empreendedor como figura central em qualquer organização.

Relevância/Originalidade: O presente artigo faz algo inédito do ponto de vista conceitual. Alguns acadêmicos discutem a importância de indivíduos que detém e exercem poder nas organizações, no entanto, ao usar a teoria empreendedorial da firma, damos um passo inédito nas discussões de marketing estratégico.

Implicações sociais ou para administradores: Ao adotar uma abordagem individualista para a análise do marketing estratégico, acadêmicos aumentam a quantidade de ferramentas à sua disposição para compreender o dinamismo organizacional e mercadológico. Tal abordagem também contribui para aproximar as discussões teóricas a algo mais palpável para os práticos.

Palavras-chave: Marketing estratégico. Empreendedorismo. Inovação. Teoria empreendedorial da firma.

\section{Como citar}

American Psychological Association (APA)

D'Andrea, F. A. M. C., \& Luce, F. B. (2021, jul./set.). Uma perspectiva de marketing estratégico sobre empreendedores e inovação. Revista Brasileira de Marketing - ReMarK, 20(3), 595-625. https://doi.org/10.5585/remark.v20i3.16322. 


\section{Introdução}

O marketing estratégico (ME) busca entender a abordagem da organização para com o mercado. Isto é, como a firma se posiciona para competir e sobreviver. A inovação é uma característica necessária para a sobrevivência. A inovação está presente, ainda que não sempre explicitamente, em toda a discussão sobre empreendedorismo e sobre ME. Porém, o ME raramente discute a figura do empreendedor, sua influência sobre as decisões da organização e as consequências destas decisões sobre o mercado.

Os estudos em inovação são, muitas vezes, partes dos estudos em estratégia e embora o trabalho em equipe a gestão da inovação sejam e permaneçam enormemente importantes, a inovação é natural e exclusivamente uma possibilidade individual, empreendedora. Esta conexão entre empreendedorismo e inovação (Bylund, 2016) geralmente é ignorada e precisa ser melhor explorada pelos acadêmicos de marketing, em especial pelo fato de que tem implicações profundas para o ME. A ausência da teoria do empreendedor no ME é o que este artigo busca solucionar.

A inovação é central para a teoria em marketing (Day \& Wensley, 1983). Em particular, o ME vê a inovação como fundamental (Finoti, Didonet, Toaldo, \& Costa, 2018; Hunt, 2015, 2018; Varadarajan, 2010, 2015). Embora existam relações intrínsecas entre marketing e empreendedorismo - empreendedores guiam ou são guiados pelo mercado - muito pouco é dito em marketing sobre os empreendedores em geral, a literatura tende a falar sobre administradores ou gestores (managers) (Hultman \& Hills, 2011) e sobre marketing em pequenas e médias empresas (PMEs) (Bocconcelli et al., 2018; Dzogbenuku \& Keelson, 2019). Por conta destes focos, o fato de os empreendedores serem a fonte última da inovação tende a passar despercebido. Como dito anteriormente, em administração e em marketing em particular, o papel do empreendedor em influenciar as decisões sobre como a empresa deve se posicionar no mercado para melhor competir e a consequente performance da organização permanecem majoritariamente fora da discussão acadêmica. A ligação entre o indivíduo que origina o fato, o empreendedor, e sua criatura, a maneira com a qual organização encara o mercado, desaparece.

Neste sentido, mesmo áreas que usam os termos em conjunção, por exemplo o "Marketing Empreendedor" ou a "Interface Marketing/Empreendedor", não consideram o papel desempenhado pelo empreendedor enquanto agente. Estas áreas tendem a focar em aplicações e em sugerir como técnicas de administração de marketing devem funcionar quando aplicadas as perspectivas de novas empresas, trabalhadores autônomos, negócios familiares ou 
PMEs (vide, por exemplo: M. Miles, Gilmore, Harrigan, Lewis, \& Sethna, 2015; and Stokes, 2000). A literatura sobre a aplicação de técnicas de administração de marketing no contexto do empreendedor é vasta. O que ainda precisa ser explorado é: qual o real impacto e qual a relevância do empreendedor para as decisões de marketing estratégico da organização?

O marketing estratégico lida com a maneira com a qual as organizações devem se comportar num mundo dinâmico (Hunt, 2015; Varadarajan, 2019). Consequentemente, o ME lida com as possíveis consequências da inovação ou falta desta para tais organizações e para a sociedade como um todo (um tratamento mais detalhado sobre isso é feito na seção 1 deste artigo). O foco no consumidor é o início para toda a pesquisa em orientação para mercado. A pesquisa em orientação empreendedora veio em seguida, tentando compreender como as organizações podem emular o comportamento de empreendedores de sucesso. Além disso, conceitos como: a análise estrutural da indústria (structure-conduct-performance - SCP); a visão baseada em instituições (Institutional Based View - IBV); e a visão baseada em recursos (Resource-Based View - RBV) com as capacidades dinâmicas (dynamic capabilities - DC); devem ser usadas como suporte para uma discussão de ME que tenha por fundamento a inovação e guiada pelo individualismo metodológico representado na ação empreendedora.

Com base nestes fundamentos, o artigo busca inserir na discussão em ME a teoria empreendedorial da firma (Bylund, 2016; Foss \& Klein, 2012) e esclarecer as conexões entre as duas. Uma estrutura que conecta ME, como entendido por Varadarajan (2010) e Hunt (2015), é apresentado, ao mesmo tempo, a inovação é fundamentada no tipo de empreendedor que guia a organização. Esta estrutura une literaturas anteriormente separadas e é capaz de guiar pesquisas futuras que poderão ajudar a melhor compreender as organizações e a inovação como consequências da ação empreendedora partindo de uma perspectiva de marketing estratégico. Quanto ao método, ao inserir a perspectiva individualista que considera o indivíduo como causa fundamental dos fenômenos da sociedade, incluindo aqueles organizacionais (Rothbard, 1976), o artigo traz uma visão complementar ao paradigma positivista mais comum na academia em marketing. Esta abordagem responde aos chamados de maior inter e multidisciplinaridade, tidos como necessários para a compreensão de fenômenos complexos, como os estudados pelas ciências sociais.

O trabalho segue da seguinte maneira: a primeira parte apresenta como o ME lida com a inovação e apresenta o tripé do ME. A segunda parte discute o empreendedor. Na terceira são apresentadas as complementariedades entre as literaturas e uma estrutura que as conecta, bem 
como a uma tabela que relaciona os termos usados nas literaturas. Sugestões de pesquisas futuras e limitações do trabalho são apresentados na última parte do texto.

\section{Marketing (Estratégico) e Inovação}

O marketing lida com aquilo que é relevante para a idealização, a produção, a comunicação e a distribuição de produtos e serviços que podem ter valor para um grupo de consumidores ou clientes. É importante ressaltar que estes produtos ou serviços podem ter valor, visto que nem todas as atividades de marketing são feitas em suporte a produtos que acabam por ter sucesso, pelo contrário, uma parte significativa das atividades de marketing é executada antes da existência de alguma oferta no mercado e, em alguns casos, embora tais atividades tenham sido realizadas da maneira "correta", uma oferta comercial pode não encontrar uma demanda mercadológica que a faça ter sucesso. O marketing surgiu como uma maneira de melhor compreender os mercados (Oliveira, Moretti, \& Silva, 2017; Shaw, Jones, \& McLean, 2011), e as necessidades dos consumidores a fim de criar e posicionar propostas de valor que tem por objetivo atender às demandas dos consumidores. Infelizmente, porém, tais origens tendem a ser negligenciadas pela produção acadêmica contemporânea. A discussão em marketing hoje está majoritariamente centrada em impactos de curto prazo e métodos de mensuração, por exemplo, a expectativa de Malhorta (2018, p. 652) de que mais decisões de marketing deverão se tornar automatizadas é um exemplo bastante recente deste direcionamento da disciplina (veja também Mazzon, 2018).

Outras áreas acadêmicas, tanto dentro quanto fora da administração, tendem a ver o marketing como tendo como maior responsabilidade aquela de gerar resultados (rápidos) de vendas através da aplicação de técnicas de administração de marketing. Esta maneira de enxergar o marketing é tão disseminada que as pessoas, incluindo alguns acadêmicos, erroneamente definem o marketing simplesmente como administração de marketing ou táticas de marketing (Varadarajan, 2010). Um fato que ilustra tal fenômeno é que menos de um terço dos vice-presidentes de marketing desempenham funções estratégicas e estes profissionais tendem a ser trocados muito rapidamente caso resultados de curto prazo não sejam alcançados de maneira satisfatória (Whitler \& Morgan, 2017). A parte estratégica do marketing é negligenciada pela maioria dos acadêmicos da área e, por isso, o marketing perde influência também entre os práticos em suas decisões estratégicas (Homburg, Vomberg, Enke, \& Grimm, 2015). Apesar disso, o marketing não se resume ao marketing mix e tende a funcionar muito 
melhor quando trabalha com objetivos estratégicos (Driest \& Weed, 2014; Germann, Ebbes, \& Grewal, 2015).

De maneira concomitante e complementar, a ‘naturalização das ciências sociais’ (E. W. Miles, 2016) invadiu a academia e esta explícita no foco cada vez maior em método e mensuração (Malhotra, 2018; Mazzon, 2018; Vargo, 2018). Além disso, o surgimento da disciplina acadêmica de estratégia como uma literatura específica, a superespecialização do marketing evidenciado no surgimento de diversas subdivisões e o movimento de "método acima de significado" (method over meaning), também contribuíram de maneira conjunta para a escassa relevância do marketing na parte estratégica das organizações, de maneira que a maioria das discussões modernas nesta área de especialização são guiadas por método e dados, não pelos eventuais tópicos de interesse (Falcão, Ikeda, \& Campomar, 2017; Hunt, 2002; Reibstein, Day, \& Wind, 2009).

Esta orientação estratégica, no entanto, permanece viva no Marketing Estratégico (ME). Esta é uma parte da disciplina que lida com conceitos e processos que guiam as organizações em direção à busca da vantagem competitiva (Hunt, 2015). Esta subárea herdou a agenda mais robusta do marketing como era visto inicialmente. Seu objetivo é compreender mercados e indicar como as organizações devem se comportar para melhor atendê-los. Seus objetivos são de médio longo prazo e ela engloba o estudo de fenômenos organizacionais, intraorganizacionais e ambientais que tem relação com o comportamento das organizações no mercado e nas suas interações com os diversos tipos de consumidores, competidores e outros agentes externos (Varadarajan, 2010, p. 126).

Marketing estratégico e estratégia de marketing não devem ser confundidos. ME lida com a estratégia organizacional (Matos, Matos, Martins, Rosa, \& Bernardon, 2018; Varadarajan, 2010). Ao mesmo tempo, estratégias de marketing vistas na administração de marketing, também conhecidas como táticas de marketing, fazem parte de um campo muito mais estreito, que estuda os esforços organizacionais direcionados à criação, comunicação, preço e promoção de ofertas.

O ME lida inerentemente com o dinamismo do mercado, por isso ele precisa lidar com a maneira pela qual as organizações mudam com o passar do tempo. Desta maneira, o fundamento mesmo do ME está diretamente relacionado com a inovação e suas consequências para a performance, incluindo a perpetuação ou o desaparecimento de qualquer organização. A inovação é endógena aos mercados, pode se dizer que é sua característica fundamental (D’Andrea \& Mazzoni, 2019). O mesmo dinamismo que forca os empreendedores a pensarem 
sobre como agir no mercado é necessário e presente no ME das organizações, tal dinamismo se torna visível na busca pela inovação nas organizações.

Neste tópico, é importante esclarecer as diferenças entre inovação e invenção. Inovação depende de invenção, mas enquanto invenção pode ser definida como qualquer coisa nova, inovação deve ser compreendida como a introdução comercial de algo novo em determinado mercado (Fagerberg, 2006). Inovação é mudança que tem impacto positivo nas finanças organizacionais (Nobrega \& Lima, 2010). De uma perspectiva puramente subjetivista, o lucro financeiro é somente uma parte do lucro total que o empreendedor de sucesso consegue recolher. Como consequência, em teoria é possível que uma inovação ocorra mesmo que não traga benefícios financeiros para a firma, isto pode ocorrer caso o empreendedor creia que tal modificação seja psicologicamente benéfica - que haja um "lucro psíquico" - isto, porém, não deve ser o mais comum em organizações que visam lucro, como é comum no mercado.

Um ponto central é que as inovações só podem ser classificadas como tais a posteriori, como consequência, não é possível "investir em inovação". Só é possível investir em esforços para que a inovação possa ocorrer e é isso que os empreendedores fazem (Bylund, 2016). Nem todos os acadêmicos aceitam que empreendedores são essencialmente indivíduos que investem em esforços para que a inovação ocorra, a divisão teórica entre imitadores e inovadores ilustra este ponto (Kirzner, 1973; Packard \& Bylund, 2018). Apesar disso, neste trabalho, adota-se o entendimento que iguala o agente econômico individual, o empreendedor, com o ato de buscar inovar (Bylund 2016). Além disso, independentemente do entendimento particular de cada acadêmico, é inegável que empreendedores tem sempre por base o dinamismo, a inovação, a mudança, partindo daí é que eles colocam em prática suas idéias e ações de ME.

Os esforços para inovação são naturalmente incertos, esta incerteza leva acadêmicos e práticos a buscarem caminhos e soluções para os problemas comuns desta caminhada. Estes esforços buscam melhor compreender e sistematizar processos que geralmente levam a esforços de inovação que obtém sucesso, estas maneiras de organizar o processo tem como objetivo reduzir a variabilidade e fazer com que o esforço de inovação seja mais organizado e previsível. Este objetivo acaba por se transformar nas diversas abordagens de gestão da inovação, que podem ser divididas em dois campos, os da inovação fechada e aberta. No paradigma da inovação fechada o foco é no desenvolvimento interno (geralmente ligado à tecnologia) e em suas aplicações a novos produtos (Pavitt, 2006). Este paradigma tem um impacto muito relevante sobre o marketing, pois as organizações precisam vender aquilo que desenvolveram internamente para recuperar o investimento e recomeçar o ciclo. Como o marketing é visto 
como o responsável pelas vendas, a administração de marketing e suas funções ganham relevância, o marketing estratégico é relegado à posição secundária ou inexistente. Do outro lado, no paradigma da inovação aberta (Chesbrough, 2003), o mercado está integrado no processo desde o princípio. Aqui o marketing ganha muita importância e um aspecto estratégico, pois a compreensão do mercado se torna essencial para os desenvolvimentos de propostas de valor que, idealmente, preencham lacunas existentes ou a serem criadas no mercado.

A moderna abordagem das 'capacidades de inovação' também tem conexões importantes com o ME ao dizer que a inovação pode ser construída em várias partes da organização. Além disso, as capacidades de inovação se dividem em dois drivers, um de tecnologia e um de negócios, cada um desses se subdivide em duas capacidades (de desenvolvimento e operação; e de administração e transações, respectivamente) (Alves, Barbieux, Reichert, Tello-Gamarra, \& Zawislak, 2017). Inovações que ocorrem no driver de negócios tendem a ser mais difíceis de imitar/emular/copiar e tendem a levar a uma vantagem competitiva de maior duração quando comparadas às inovações de tecnologia.

\subsection{Orientação Estratégica e abertura à inovação}

A maneira com a qual as organizações enfrentam o dinamismo do mercado pode ser analisada de um ponto de vista da inovação. Isto não é o mesmo que falar sobre os paradigmas de inovação aberta e fechada, mencionados anteriormente. Tanto na inovação aberta quanto na fechada há um interesse por parte da organização de buscar o dinamismo, porém isto é feito de maneira diferente em cada um dos casos. A discussão que será feita aqui é se refere à seguinte pergunta: a organização está aberta à mudança e a inovação?

Organizações que respondem positivamente serão ou não capazes de acompanhar o dinamismo do mercado. De outro lado, as organizações que evitam a inovação terão dois caminhos possíveis: 1. elas terão um mercado estático e continuarão seu sucesso passado, o que é muito difícil de acontecer, ou 2. elas enfrentarão um mercado dinâmico que irá expulsá-las mais cedo ou mais tarde. É importante lembrar que nem todas as organizações querem mudar e que algumas não são capazes de mudar, ainda que queiram (Houston, 1986).

Dentre as organizações que estão dispostas a inovar, como base no "conceito de marketing" e na ideia de "orientação para o consumidor", surge o conceito de "orientação para o mercado". Este conceito é a geração por toda a organização de inteligência de mercado sobre as necessidades dos consumidores atuais e futuros, a disseminação desta inteligência entre os 
departamentos e a responsividade de toda a organização à geração e a disseminação deste conhecimento (Kohli \& Jaworski, 1990, p. 1960). Essa abordagem constrasta com a "orientação interna" (Houston, 1986), para organizações que adotam esta segunda postura, a geração de inteligência pode ser insuficiente, pois esta não é aplicada nos esforços de inovação. Esta visão mais estreita da Orientação para o Mercado pode ser incapaz de gerar vantagem competitiva de longo prazo pois é inerentemente adaptativa. Pelo contrário, as organizações que se baseiam na geração de conhecimento e aprendizagem sobre o mercado se tornam orientadas pelo mercado e, por estarem constantemente em busca de novidades e encontrando novas soluções a serem aplicadas em sua estrutura de produção, são mais capazes de criar vantagem competitiva mais duradoura (Weerawardena \& O'Cass, 2004). A orientação para o mercado tende a ser mais relevante quando as organizações antecipam as tendências do mercado e agem para atende-las de maneira mais rápida que a concorrência (Kumar et al., 2011). Como é impossível saber ex ante se o que parecer ser uma tendência de mercado, de fato, se concretizará, o processo de inovação é sempre incerto.

A literatura de ME classifica as organizações orientadas para o mercado em dois campos mutuamente excludentes: as que são guiadas pelo mercado - Market Driven - e as que guiam o mercado - Market Driving. No primeiro caso, as organizações buscam nor mercado possíveis problemas e soluções e adotam uma postura de adaptação; no segundo caso, o mercado é fonte de informações e idéias com vistas a prever ou até mesmo moldar o mercado no futuro, esta abordagem é generativa (Jaworski, Kohli, \& Sahay, 2000).

Ao mesmo tempo, algumas organizações, geralmente as de maior porte, ao buscarem um posicionamento mais propenso à inovação, buscam adotar um caminho mais empreendedor, inovador, abraçando perspectivas que se tornaram conhecidas na literatura como "orientação empreendedora". Este tipo de cultura organizacional busca inserir nas organizações, em especial as de maior porte, características peculiares aos empreendedores (quanto à tomada de decisão ou maneiras de abordar o mercado, dentre outras) de maneira a buscar modificar sua estrutura produtiva (Wales, 2016, p. 2).

\subsection{O tripe do Marketing Estratégico}

O marketing estratégico dá ao analista uma série de ferramentas para pensar de maneira sistemática sobre mercados, buscando maneiras de conseguir e desenvolver vantagem competitiva. Uma das literaturas mais conhecidas sobre o tema é a análise estrutural da indústria (structure-conduct-performance - SCP) (Porter, 1985). 
Uma segunda tradição é a visão baseada em recursos (Resource-Based View - RBV) (Barney \& Arikan, 2001) com as capacidades dinâmicas (dynamic capabilities - DC). Esta sugere que as organizaçoes são combinações de recursos heterogêneos e que para atingir vantagem competitiva, a organização precisa organizar os recursos de maneira mais lucrativa que seu concorrente médio. Para gerar vantagem, os recursos precisam ser relativamente únicos, raros, imóveis e devem ter oferta relativamente inelástica (Barney \& Arikan, 2001). As vantagens que vem desses recursos só podem ser sustentadas ao longo do tempo com adaptação contínua. As capacidades dinâmicas complementam a RBV e dão uma explicação teórica para a fonte do dinamismo. São as capacidades dinâmicas de inovação que fazem com que seja possível que as organizações guiem o mercado ou sigam as mudanças impostas por ele (Teece, 2007).

A visão baseada em instituições (Institutional Based View - IBV) (Peng, 2002) é a terceira parte do tripe. Esta abordagem reconhece que cada sociedade é formada por instituições diferentes e que tais instituições influenciam todas as transações que ocorrem nessas sociedades, além disso, este arcabouço institucional facilita a existência do mercado dado que ajuda a reduzir a incerteza.

A IBV olha para o ambiente de maneira mais geral, considera as regras do jogo que governam a sociedade onde a organização está inserida; a SCM olha para a empresa de uma perspectiva mais estreita, da indústria; por fim a RBV e as DC olham a organização desde dentro. A literatura em ME tem muito a se beneficiar ao usar estas três visões complementares e tratá-las como necessárias para a geração de vantagem competitiva. As três formam o tripé do marketing estratégico e suportam o pensamento analítico sobre o mercado no qual a organização está inserida. Embora estes três elementos sejam muito relevantes, falta nesta análise uma relação direta com o elemento humano. A figura que falta é exatamente a do empreendedor - ou o indivíduo exercendo a função econômica do empreendedor naquele ambiente específico -, esta pessoa é quem vai absorver e processar a informação e vai, ao empregar os recursos com base na sua avaliação subjetiva, decidir como cada organização deve se comportar no mercado. O empreendedor é a parte que falta, e fortifica a análise do tripé do ME ao leva-la a outro nível. 


\section{Empreendedor como conceito}

Nem todas as ações humanas são relevantes para as organizações, mas, de certa maneira, toda ação humana é empreendedora. Em administração a discussão sobre o empreendedor é muito extensa (Chandra, 2018). Empreendedores são vistos como importantes para o desenvolvimento econômico e social (Powell, 2007) e as escolas de negócios tem tentado ensinar empreendedorismo por algum tempo. Porém, a abordagem individualista que considera o empreendedor como a substância fundamental de qualquer organização geralmente não é tratada. Ao unir este entendimento com o conceito de mercado como um processo ${ }^{1}$, é possível melhor compreender as consequências do empreendedorismo nos mercados. Na tradição do individualismo metodológico que lida com empreendedorismo existem duas tradições teóricas complementares, uma que pode ser representada por Kirzner's (1973) e uma segunda, representeada por Foss \& Klein's (2012).

Kirzner (1973) diz que os empreedendores usam um estado especial de atenção, de alerta (alertness no original) para observar, agir, e lucrar com oportunidades de mercado que, segundo o entendimento mais aceito, são características inerentes ao mercado mesmo, isto é, nesta tradição as oportunidades são fenômenos objetivos, acessíveis a qualquer individuo em determinado mercado em determinado tempo. Empreendedores são mais capazes que outros agentes de ver as pré-existentes oportunidades de arbitragem e agem sobre elas para lucrar (Phelan, 2016). Para esse tipo de empreendedor, o futuro é quase que previsível e as possibilidades de ação são relativamente finitas. Este entendimento é debatido por vários autores, o próprio Kirzner (2009) critica este debate, afirmando que se trata de uma compreensão errada de suas ideias.

Foss \& Klein (F\&K) (2012) adicionam o conceito de incerteza inicialmente desenvolvido por Frank Knight (1921) e sugerem que os empreendedores imaginam o futuro e tentam transformar a realidade na direção que lhes parece a correta. O papel deste agente esta ligado à reunir e usar recursos sob sua propriedade (ao menos parcial) enquanto enfrentam as incertezas que advém da impossibilidade de possuir conhecimento perfeito sobre o passado, o presente e o futuro. Este empreendedor usa julgamento (judgment) e os recursos tangíveis e intangíveis sob seu controle para decidir, ele age para atingir os objetivos que, às vezes, somente

\footnotetext{
${ }^{1}$ A ideia do mercado como um processo leva à conclusões similares às da idéia da destruição criativa (Schumpeter, 1942), porém existem profundas diferenças metodológicas entre os dois argumentos teóricos, em particular estas diferenças estão na endogeneidade da inovação, inerente ao processo de mercado e proveniente de um choque externo ao mercado na outra explicação (veja BoStaph, 2013, p. 421). Este fato não pode ser ignorado por analistas de mercados dinâmicos como quaisquer acadêmicos interessados em marketing estratégico devem ser.
} 
ele é capaz de antever. Este empreendedor guia a inovação ao aplicar conhecimento de maneira a usar os recursos de uma maneira fora do usual. Ao fazer isso ele elimina o bloqueio da especialização - specialization deadlock, vide Bylund (2016), alargando a estrutura de produção do mercado enquanto mantém as conexões necessárias com esta mesma estrutura, de quem ele deve comprar os insumos e para quem deve vender seus produtos (Bylund, 2016, p. 45). Para este tipo de empreendedor, 'oportunidades' são subjetivas, pessoas diferentes, ainda que em circunstâncias exatamente iguais, agirão de maneira diferente pois 1. elas têm acesso diferente e pensam diferentemente sobre os meios de produção à disposição, e 2. elas anteveem fins diferentes. Neste tipo de entendimento, oportunidades dependem não somente do mercado, que dá a sustentação e a base para a criatividade empreendedora, mas principalmente no agente; as possibilidades são muito maiores quando comparadas ao caso do empreendedor em Kirzner (1973) e são limitadas pela capacidade do agente em prever o que ele pretende fazer e quais recursos existem à sua disposição para tanto.

Para a teoria do empreendedorismo, e do ponto de vista dos estudos em marketing estratégico, estas visões são complementares (BoStaph, 2013; Foss \& Klein, 2017; Kirzner, 2009; Phelan, 2016). O empreendedor de Kirzner age com base no mercado presente e acredita que o mercado futuro será similar, assim, ele tenta explorar oportunidades ao criar firmas que são similares àquelas que já existem, ou, em alternativa, busca melhorar a produtividade de um processo pré-existente; este tipo de empreendedor lida com riscos mensuráveis e suas ações são incapazes de modificar fundamentalmente um mercado ou de expandir a Fronteira de Possibilidades de Produção (FPP). Por outro lado, os empreendedores do tipo F\&K, prestam atenção especial aos recursos disponíveis e aos seus objetivos individuais. Este tipo de empreendedor enfrenta a incerteza e tentará criar algo novo e único, quando ele tem sucesso, suas ações expandem a FPP e o mercado como um todo (vide Figura 1b). Essa abordagem é similar à de Schoemaker \& Day (2018, p. 703).

O empreendedor de Kirzner trabalha com as possibilidades que existem no presente, o de F\&K imagina novas possiblidades.

\subsection{Uma estrutura integrada: ME, inovação e empreendedorismo}

A presente seção sugere uma estrutura que integra os conceitos previamente discutidos. Esta estrutura funciona como uma estrutura conceitual básica. É uma maneira lógica e sistemática de organizar os fenômenos. Serve para identificar as variáveis relevantes ou componentes em termos de maneiras pelas quais eles se relacionam uns com os outros (Kuratko, 
Morris, \& Schindehutte, 2015, p. 3). A estrutura conecta os conceitos e demonstra como se complementam. ME e empreendedorismo, embora apresentem jargões, denominações e tratamentos diversos, tem muito em comum, em especial quando vistos de uma perspectiva fundamental dada pela inovação.

\section{Empreendedores e suas ações no Mercado}

A ação empreendedora leva ao desenvolvimento de organizações Market Driven ou Market Driving. Tais organizações são entidades coletivas que, por definição, são incapazes de agir. Por si só, nenhuma organização é capaz de modificar a estrutura de produção, ou inovar. Somente indivíduos são capazes de agir e inovar, eles geralmente fazem isso dentro das organizações e em nome delas. A inovação é impossível se não houver o agente, o decisor, o empreendedor. Com vistas a apresentar a estrutura anteriormente citada, o primeiro passo é partir do conceito de economia uniformemente circular (Evenly Rotating Economy - ERE). Este é um conceito teórico, um modelo no qual não existe inovação, pois não há mudança nas preferências dos indivíduos e nem na disponibilidade de recursos (Elias, Chiles, Li, \& D'Andrea, 2020; Rothbard, 2004). Partindo deste ponto de vista, os empreendedores usarão suas organizações para implementar seus planos. O primeiro passo a ser dado é que o empreendedor deve decidir / escolher qual será a orientação estratégica da organização sob seu comando. Como inovar? Seguir o mercado ou liderar a inevitável mudança? ${ }^{2}$ As Figuras 1a e 1b representam as ações empreendedoras e as consequentes abordagens estratégicas das organizações que estes empreendedores guiam no mercado. Os quadrados são oportunidades no sentido dado à esta palavra por Kirzner - disponíveis em determinado momento no tempo; os círculos são possíveis caminhos que os empreendedores do tipo $\mathrm{F} \& \mathrm{~K}$ podem imaginar e seguir. Nos dois casos, os empreendedores terão que direcionar recursos em busca de algum tipo de mudança. Algumas coisas a serem notadas nas figuras:

1. Figura 1a é o mundo na ERE, na Figura 1b, as suposições da ERE são relaxadas e o mercado funciona como na vida real (não-ERE);

\footnotetext{
${ }^{2}$ Parece muito claro que a enorme marioria dos empreendedores não pensa desta maneira, de fato, é provável que os empreendedores não se importem em pensar de maneira tão técnica sobre o assunto ou tenham algum interesse nas teorias que buscam entender seu comportamento ou as consequências destes comportamentos. Ao mesmo tempo, também é fato que organizações de sucesso tendem a escolher caminhos específicos e tendem a ser capazes de reconhecer algumas possíveis maneiras de atender aos seus respectivos mercados.
} 
2. Nas Figuras 1a e 1b, existem oportunidades Kirnzerianas não exploradas dentro do mercado atual (dentro da atual FPP), enquanto isso, as 'oportunidades' do tipo F\&K, que dependem muito mais da criatividade do agente, estão além da atual FPP;

3. A partir do momento em que o empreendedor Kirzneriano age, o mercado para ação imitativa é reduzido, como fica claro na comparação entre os tamanhos do retângulo cinza na Figura 1a e do retângulo interno branco na Figura 1b, isto é, depois da ação deste empreendedor, as chances de sucesso derivadas da simples cópia/emulação de uma solução (uma estrutura ou um método de produção) já existente dentro desta FPP diminuem;

4. Ao mesmo tempo, assim que o empreendedor do tipo $\mathrm{F} \& \mathrm{~K}$ age, o mercado se expande, observe como a retângulo em cinza-claro na Figura 1 b que representa a FPP aumenta quando comparado ao retângulo em cinza-escuro na Figura 1a.

5. Dentro da FPP não-ERE na Figura 1b, novamente, somente empreendedores do tipo Kirznereiano agirão. 'Oportunidades' para empreendedores do tipo F\&K aparecem fora da atual FPP e são representados pelo mercado potencial ainda não explorado que pode ser visto em branco no retângulo mais externo na Figura 1b.

6. Por conta da ação dos empreendedores do tipo F\&K, o tamanho do mercado para os empreendedores Kirznerianos aumenta, existe agora um mercado maior para buscar oportunidades do tipo imitativo;

7. Tanto em 1a quanto em $1 \mathrm{~b}$, as possibilidades para empreendedores do tipo $\mathrm{F} \& \mathrm{~K}$ surgem fora da atual FPP e dependerão do julgamento e da ação destes empreendedores para se tornarem realidade. É claro que novas empresas que atuem mais próximo da atual FPP, ou seja, mais próximas do que o mercado atual já comporta, serão mais facilmente concebíveis e mais facilmente transformadas em realidade. Por exemplo, seria relativamente fácil pensar num telefone móvel dada a existência de um telefone fixo, o salto de andar a cavalo para viagens de avião é bem mais distante. Ambos os casos são, em teoria possíveis e até similares, na prática, as dificuldades para o segundo caso seriam muito maiores que para o primeiro.

O fenômeno se repete todas as vezes que um empreendedor do tipo F\&K age. Ele expande o mercado e insere dinamismo, ele provoca mudança não somente para a sua organização, mas no mercado como um todo (ele expande a FPP ao se livrar do bloqueio da especialização previamente existente e alarga a estrutura do processo produtivo no qual está inserido). Ao mesmo tempo, o empreendedor Kirneriano empurra o mercado em direção ao 
equilíbrio, reduzindo as oportunidades para os agentes que estão simplesmente 'alerta' naquele mercado todas as vezes que eles agem sobre alguma dessas oportunidades. Os dois tipos de atividade empreendedora são necessários e podem ser vistos em qualquer mercado que esteja em funcionamento normal. Em conjunto, eles representam o dinamismo do processo de mercado pois 1. expandem a FPP e 2. aumentam cada vez mais a produtividade dos atuais processos (D’Andrea \& Mazzoni, 2019; Packard \& Bylund, 2018).

Figura 3 - Mercados antes e depois da ação empreendedora

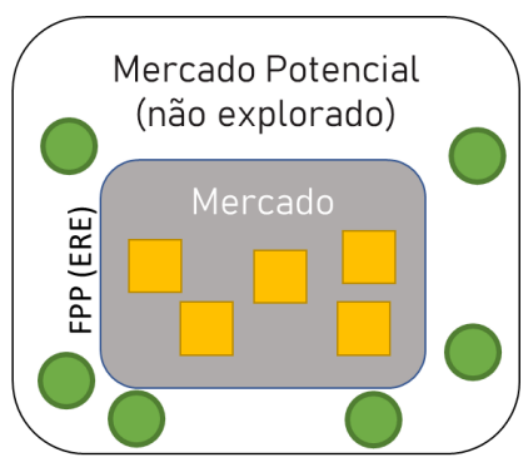

Figura 1a: o mercado está na ERE, oportunidades existem, mas ninguém age sobre elas

Oportunidades Kirznerianas 'Oportunidades' do tipo F\&K

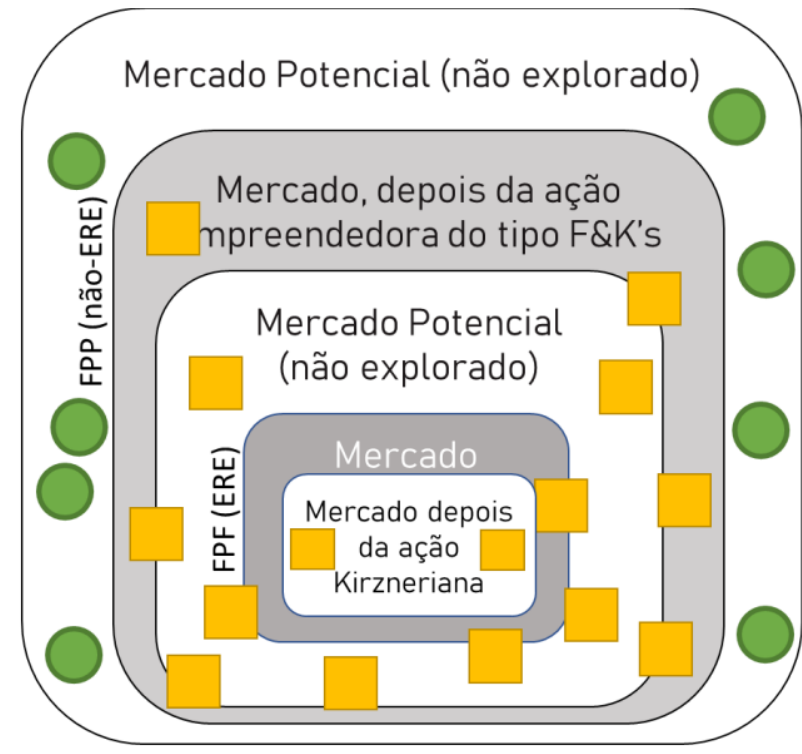

Figura 1b: a hipótese da ERE foi relaxada. As Oportunidades foram exploradas por empreendedores Kirznerianos e do tipo F\&K

Fonte: Os autores.

O mercado depois da inovação, quando a hipótese da ERE é relaxada, é diferente nos dois arranjos de ação empreendedora/marketing estratégico. No arranjo que decorre da ação do empreendedor Kirzneriano, sem a ação do empreendedor do tipo F\&K, as inovações serão puxadas pelo mercado, haverá uma tendência ao equilíbrio e menos oportunidades para outros empreendedores Kirznerianos, os processos produtivos tenderão a ficar cada vez mais semelhantes e a competição tenderá cada vez mais a se dar pela produtividade e a ser baseada em preços, vantagens competitivas tenderão a ser de curta duração ou mesmo a não existir e a inovação será incremental. 
Por outro lado, organizações/empreendedores do tipo F\&K expandem o mercado e, ao expandir a FPP ao se livrar do bloqueio da especialização, acabarão por oferecer uma maior gama de oportunidades quando comparado ao que havia antes desta ação empreendedora para os dois tipos de empreendedores (veja como a Figura $1 \mathrm{~b}$ apresenta mais possibilidades que a Figura 1a). Ao mesmo tempo, a inserção de inovações que modificam o mercado irá empurrar o mercado para direções anteriormente inesperadas, estas modificações mais profundas dão ao empreendedor que as executa uma vantagem maior, visto que as maiores modificações fazem com que seja mais difícil para competidores imitarem as ações. Este tipo ação tende a um mercado mais desequilibrado por conta de suas inovações mais radicais.

\subsection{Uma estrutura de ME baseada na ação empreendedora}

A Figura 2 apresenta a estrutura que une as ideias de empreendedorismo e marketing estratégico. A representação mostra que, dependendo do qual rota o empreendedor escolher traçar, ele precisará estar atento a diferentes variáveis estratégicas e um grupo diferente de decisões será o pilar da luta da organização para conseguir vantagem competitiva e se manter no mercado.

Se o empreendedor optar por uma empresa do tipo Kirzneriano, a organização deverá ser baseada em IBV, SCP e RBV. Tal organização olhará para o mercado e tentará se adaptar às necessidades e desejos dos consumidores da melhor maneira possível dada a limitação de recursos. Esta empresa será Market Driven, em outras palavras, ela seguirá o mercado. As inovações incrementais, e idealmente constantes, serão puxadas pelas necessidades mercadológicas mais ou menos explícitas (veja os quadrados amarelos nas Figuras 1a e 1b). Este tipo de empreendedor usa causation (Sarasvathy, 2009). A vantagem competitiva que esse tipo de inovação trará tende a ter curta-duração pois é relativamente fácil imitar tais movimentos - estes são empreendedores imitadores no jargão de Bylund (2016). Empreendedores Kirznerianos e as empresas que derivam deste tipo de ator serão ameaçados pelos competidores Kirznerianos e pelos empreendedores do tipo F\&K, com suas empresas que modificam mercados.

De maneira complementar, o empreendedor modelo do tipo F\&K olha para o mercado e organiza os recursos para competir em um mercado que ainda não existe e no qual ele será o único competidor até que outros comecem a imitar suas inovações (veja os círculos verdes nas Figuras 1a e 1b). A organização que advém deste tipo de ator não somente se baseia em IBV, $\mathrm{SCM}$ e RBV, ela também usa julgamento empreendedor (entrepreneurial judgment) que 
adiciona as capacidades dinâmicas (DC) aos três elementos previamente mencionados com o objetivo de criar vantagem competitiva. Ao invés de causation esse empreendedor usa effectuation (Sarasvathy, 2009).

Empreendedores do tipo F\&K empurrarão o mercado na direção que eles julgam ser a melhor para as suas intenções particulares. Eles irão direcionar o mercado através da implantação de mudanças que farão com que as pessoas e os mercados mudem de maneira substancial - ao se livrarem das antigas formas de produzir, iniciando outras, geralmente mais detalhadas e complexas (Bylund, 2016). Neste processo, estes empreendedores destroem uma parte significativa do mercado que existia anteriormente e que até então poderia ser explorado por empreendedores Kirznerianos (compare as Figuras la e 1b e observe que o mercado inicialmente disponível para o empreendedor Kirzneriano é maior na ERE, antes da introdução da inovação que muda o mercado). Isto tende a reduzir a presença de empreendedores Kirznerianos neste mercado específico. Porém, ao mesmo tempo, um mercado globalmente maior emerge (veja o retângulo em cinza-claro na Figura 1b), neste novo mercado, a estrutura de produção é mais longa e, como consequência, oferece possibilidades mais diversas de ação para os empreendedores de ambos os tipos. Esse é o mecanismo clássico de destruição criativa, porém, nesta explicação, ele é visto de um ponto de vista metodológico mais coerente. Afinal, não é um choque externo que modifica o mercado e destrói a indústria, mas um processo inerente ao mercado, o surgimento de novas indústrias, com processos produtivos mais longos e elaborados, tende a diminuir a possibilidade de ação em arranjos industriais mais antigos ao mesmo tempo que aumenta as possibilidades de ação como um todo.

Em suma, empreendedores do tipo $F \& K$ desequilibram mercados e aumentam as possibilidades de ação para todos os outros atores, incluindo empreendedores Kirznerianos. Esta orientação estratégica do empreendedor, quando tem sucesso, leva à vantagem competitiva de mais longo prazo por ser mais difícil e demorada para imitar/emular.

O caminho empreendedor de sucesso apresentado na parte superior da Figura 2 levará a mercados como o representado na Figura 1a, mais equilibrados, com uma quantidade menor de oportunidades de arbitragem e menos lucrativo na média por conta da competitividade entre organizações similares (como explicam Packard \& Bylund, 2018). O segundo caminho que o agente pode seguir, presente na parte inferior da Figura 2, levará a um mercado mais similar àquele visto na Figura $1 b$, com maiores possibilidades de ação para os dois tipos de empreendedor. 
Figura 4 - Estrutura que conecta elementos de marketing estratégico e empreendedorismo

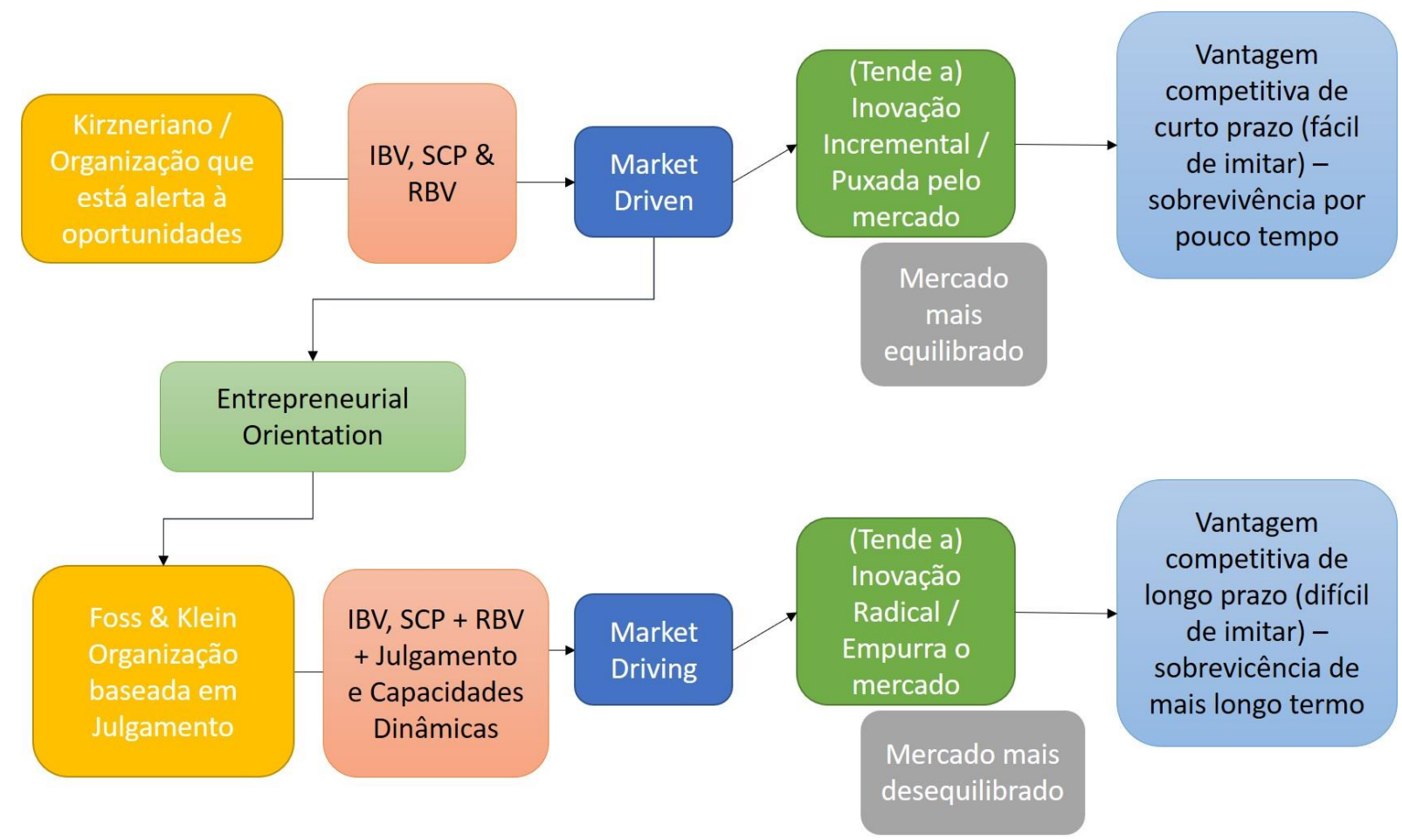

Fonte: Os autores.

Claramente os dois tipos de empreendedor/empresa, mesmo que usando abordagens substancialmente diferentes, são capazes de atingir resultados financeiros positivos - é provável, porém, visto aquilo que já foi exposto, que os volumes sejam substancialmente diferentes. A maior diferença provavelmente está na diferente capacidade de sustentar o fluxo financeiro ao longo do tempo com base no tipo de dinamismo que cada um dos dois modelos adota. Olhando para este aspecto, a inovação no ambiente específico dará à organização vantagem competitiva por um período de tempo maior ou menor? As organizações em geral pretendem continuar tendo sucesso, desta maneira, seria do interesse delas adotar uma postura de guiar o mercado (Market Driving) ao invés de ser guiado por ele (Market Driven). Neste sentido, a orientação empreendedora pode ser usada para tentar transformar uma organização Kirzneriana em uma mais propensa as idéias de Foss \& Klein, pois esta última tende a focar na busca de vantagens competitivas de mais longo prazo 
Outra coisa relevante na estrutura vista na Figura 2 é a existência das capacidades dinâmicas nas organizações que adotam uma postura baseada no tipo de empreendedor de $\mathrm{F} \& \mathrm{~K}$, esta é a característica que as distingue quando comparadas às organizações Kirznerianas. Ao adotar essa abordagem as empresas precisam se apoiar nas suas capacidades para suportar os sus conceitos de negócios (Ghauri, Wang, Elg, \& Rosendo-Ríos, 2016, p. 5683). Isto é importante por que as capacidades dinâmicas são oriundas do julgamento empreendedor. Para que as capacidades dinâmicas possam surgir, empreendedores (ou seus agentes) necessariamente precisarão exercer julgamento e agir com base naquilo que acreditam precisa ser mudado (D’Andrea \& Luce, 2020; Teece, 2007).

As DC podem ser usadas para aprender e aplicar mudanças a cada uma das três pernas do tripé do $\mathrm{ME}$, os empreendedores podem mudar as instituições usando arranjos políticos como ocorre na IBV; eles podem compreender, usando a SCP, e trabalhar para mudar a natureza da indústria como um todo a seu favor, por exemplo mudando o arranjo dos seus próprios recursos; e eles podem, principalmente, usar as DC para modificar as configurações internas da empresa, dentro daquilo que ensina a RBV. Empreendedores que são capazes de usar sua criatividade e habilidade para, através do seu julgamento e da inserção das DC, guiar as mudanças nos recursos das organizações serão mais capazes de modificar o ambiente competitivo como um todo e tenderão a ter maiores chances de sucesso.

Muitas discussões diferentes na literatura em ME lidam com estes dois tipos de abordagem empreendedorial para com o mercado e, por consequência, com os tipos básicos diferentes de organizações aos quais cada tipo de empreendedor dá origem. Porém, esta mesma literatura em ME quase nunca menciona o empreendedor que gera o posicionamento adotado pelas diferentes organizações, consequentemente a conexão entre o responsável e o fato em si permanece sem discussão.

Com o objetivo de cobrir esta lacuna na literatura e complementar o que foi previamente discutido, a Tabela 1 está dividida em três partes que apresentam uma lista de conceitos advindos do ME, da teoria do empreendedor, bem como algumas contribuições originais. As linhas iniciais para ambas as abordagens teóricas trazem conceitos amplamente aceitos e que não possuem uma referência canônica específica. Estas linhas são seguidas por referências organizadas em ordem cronológica para cada uma das duas áreas de estudo.

As fontes incluídas na Tabela 1 foram indicadas por cinco professores em cada uma das duas áreas, todos os professores contactados são professores efetivos (associate ou full professor) trabalhando nos Estados Unidos. Estes professores foram contactados por e-mail e 
o plano de ensino (de 2017 até 2020) com as referências para os cursos que que lecionam nas respectivas áreas foi pedido. Os professores também indicaram algo entre cinco e dez referências que eles consideravam as mais importantes em empreendedorismo e em marketing estratégico. Referências mencionadas nas respostas aos email ou que apareceram nos planos de ensino mais de uma vez entre os cinco professores de cada uma das duas áreas foram incluídas na Tabela 1 .

A Tabela 1 esclarece, facilita a compreensão e ajuda a conectar as ideias das literaturas de empreendedorismo e marketing estratégico de modo a facilitar o entendimento mútuo entre os pesquisadores dois dois campos e, idealmente, pavimentar caminhos para maior colaboração entre as disciplinas.

Tabela 2 - Marketing Estratégico e Empreendedorismo: conceitos coincidentes

\begin{tabular}{|c|c|c|}
\hline Empreendedor / Organização & Tipo I & Typo II \\
\hline \multicolumn{3}{|c|}{ Contribuições de Marketing Estratégico } \\
\hline Relacionado à & Estratégia & Inovação \\
\hline Melhoria & Contínua e diminuta & Grande e abrupta \\
\hline Positionamento quanto à mudança & Seguir a mudança & Liderar a mudança \\
\hline Valor para & Entrega & Desenvolvimento / criação \\
\hline Adminsitradores devem & $\begin{array}{l}\text { Trabalhar para aumentar a } \\
\text { produtividade }\end{array}$ & $\begin{array}{l}\text { Trabalhar na mudança (agir de } \\
\text { maneira empreendedora) }\end{array}$ \\
\hline Proposta de valor & $\begin{array}{l}\text { Quase indistinguível da } \\
\text { competição }\end{array}$ & $\begin{array}{l}\text { Profundamente diferente da } \\
\text { competição }\end{array}$ \\
\hline $\begin{array}{l}\text { Organização que aprende (Senge, } \\
\text { 1994) }\end{array}$ & $\begin{array}{l}\text { Adquirir conhecimento sobre } \\
\text { o mercado }\end{array}$ & $\begin{array}{l}\text { Criar conhecimento sobre mercados } \\
\text { novos }\end{array}$ \\
\hline $\begin{array}{l}\text { Competição se dá através de (Porter, } \\
\text { 1996) }\end{array}$ & Preço & Differenciação \\
\hline Tipo de inovação (Christensen, 1997) & De sustentação & Disruptiva \\
\hline $\begin{array}{l}\text { Movimentação (Lieberman \& } \\
\text { Montgomery, 1998) }\end{array}$ & Demora a se mover & $\begin{array}{l}\text { Um dos primeiros, se não o } \\
\text { primeiro a se mover }\end{array}$ \\
\hline $\begin{array}{l}\text { Abordagem mercadológica } \\
\text { (Srivastava, Shervani, \& Fahey, } \\
\text { 1999) }\end{array}$ & $\begin{array}{l}\text { Exploração do que já existe: } \\
\text { se valer dos ativos e } \\
\text { capacidades para melhorar a } \\
\text { performance }\end{array}$ & $\begin{array}{l}\text { Exploração de novos mercados: } \\
\text { construir vantagem competitiva }\end{array}$ \\
\hline $\begin{array}{l}\text { Orientação estratégica (Hill \& } \\
\text { Wright, 2000) }\end{array}$ & Market(ing) Orientation & Orientação empreendedorial \\
\hline Orientação (Jaworski et al., 2000) & Market Driven & Market Driving \\
\hline $\begin{array}{l}\text { Abordagem sobre valor (Mizik \& } \\
\text { Jacobson, 2003) }\end{array}$ & Apropriação de valor & Criação de valor \\
\hline $\begin{array}{l}\text { Estratégia do Oceano (Kim; } \\
\text { Mauborgne, 2004) }\end{array}$ & Oceano vermelho & Oceano Azul \\
\hline Negócio (Maciariello, 2009) & O que o negócio é & O que o negócio deve vir a ser \\
\hline $\begin{array}{l}\text { Tipo de aprendizagem (Kumar, } \\
\text { Jones, Venkatesan, \& Leone, 2011) }\end{array}$ & Aprendizagem adaptativa & Aprendizagem generativa \\
\hline $\begin{array}{l}\text { Tipo de posicionamento (Thiel \& } \\
\text { Masters, 2014) }\end{array}$ & Zero & Um \\
\hline Tipo de inovação (Hunt, 2015) & Reativo & Proativo \\
\hline $\begin{array}{l}\text { Tipo de resposta (Wadhwani \& } \\
\text { Lubinski, 2017) }\end{array}$ & Resposta adaptativa & Resposta criativa \\
\hline
\end{tabular}




\begin{tabular}{|c|c|c|}
\hline \multicolumn{3}{|c|}{ Contribuições de Empreendedorismo } \\
\hline Principais autores & Kirzner & $\begin{array}{l}\text { Foss \& Klein (com Mises, } \\
\text { Rothbard, Salerno e Bylund) }\end{array}$ \\
\hline $\begin{array}{l}\text { Principal característica do } \\
\text { empreendedor }\end{array}$ & $\begin{array}{l}\text { Estado especial de alerta } \\
\text { "Alertness" }\end{array}$ & $\begin{array}{l}\text { Criação de Mercado / Visionário / } \\
\text { Julgamento Empreendedor }\end{array}$ \\
\hline Centro da ação & $\begin{array}{l}\text { Preços em desequilíbrio e } \\
\text { oportunidade de arbitragem }\end{array}$ & Ação sob incerteza Knightiana \\
\hline $\begin{array}{l}\text { De onde vem as dúvidas? (Knight, } \\
\text { 1921) }\end{array}$ & Risco & Incerteza \\
\hline $\begin{array}{l}\text { Grau de inovação tecnológica } \\
\text { (Schumpeter, 1942) }\end{array}$ & Incremental & Radical \\
\hline $\begin{array}{l}\text { Mudaça no mercado (Lachmann, } \\
\text { 1977) }\end{array}$ & Equilibradora & Desequilibradora \\
\hline $\begin{array}{l}\text { Tipo de agente econômico } \\
\text { (Lachmann, 1986) }\end{array}$ & $\begin{array}{l}\text { Arbitrador (às vezes } \\
\text { especulador) }\end{array}$ & Inovador (às vezes especulador) \\
\hline $\begin{array}{l}\text { Tipo de empreendedorismo (Cheah, } \\
\text { 1990) }\end{array}$ & Austríaco & Schumpeteriano \\
\hline Visão (Holcombe, 1999) & Equilíbrio & Mão invisível \\
\hline Mercado para bens (Barbieri, 2001) & Comum & Especulativo \\
\hline $\begin{array}{l}\text { Função de produção (Lundvall \& } \\
\text { Borrás, 2005) }\end{array}$ & $\begin{array}{l}\text { (quase que) perfeitamente } \\
\text { conhecida }\end{array}$ & Impossível de ser pre-estabelecida \\
\hline $\begin{array}{l}\text { Ação empreendedora (Alvarez \& } \\
\text { Barney, 2007) }\end{array}$ & Descoberta & Criação \\
\hline $\begin{array}{l}\text { Eficiência econômica (Huerta de } \\
\text { Soto, 2009) }\end{array}$ & Eficiência estática & Eficiência dinâmica \\
\hline $\begin{array}{l}\text { Atividade (Wiklund, Davidsson, } \\
\text { Audretsch, \& Karlsson, 2011) }\end{array}$ & $\begin{array}{l}\text { Atividade econômica Pre- } \\
\text { existente }\end{array}$ & Nova atividade econômica \\
\hline $\begin{array}{l}\text { Efeitos do empreendedorismo } \\
\text { (Keyhani \& Lévesque, 2016) }\end{array}$ & Equilibrante & Desequilibrante \\
\hline Arranjo de capital (Bylund, 2016) & $\begin{array}{l}\text { Muito parecido com o } \\
\text { previamente existente }\end{array}$ & (normalmente) totalmente novo \\
\hline $\begin{array}{l}\text { Tipo de empreendedor (Bylund, } \\
\text { 2016) }\end{array}$ & $\begin{array}{l}\text { Imitador, aumenta a } \\
\text { competição ao trabalhar numa } \\
\text { função de produção pré- } \\
\text { existente }\end{array}$ & $\begin{array}{l}\text { Empreendedor, rompe com o } \\
\text { modelo tradicional e estabelece um } \\
\text { método de produção novo e novos } \\
\text { passos no processo produtivo }\end{array}$ \\
\hline Perspectiva (Klein, 2017) & Oportunidade / descoberta & $\begin{array}{l}\text { Baseada em julgamento } \\
\text { (Judgement-based) }\end{array}$ \\
\hline $\begin{array}{l}\text { Natureza da ação (Packard \& Bylund, } \\
\text { 2018) }\end{array}$ & $\begin{array}{l}\text { Empreendedorismo } \\
\text { equilibrante }\end{array}$ & Empreendedorismo desequilibrante \\
\hline \multicolumn{3}{|c|}{ Contribuições Originais } \\
\hline Ferramentas para análise estratégica & SCP, IBV, RBV & $\begin{array}{l}\text { SCP, IBV, RBV \& DC (guiado pelo } \\
\text { julgamento empreendedor) }\end{array}$ \\
\hline Possibilidades de ação & $\begin{array}{l}\text { Reduzidas para o } \\
\text { empreendedor Kirzneriano } \\
\text { naquele mercado }\end{array}$ & $\begin{array}{l}\text { Aumentam as possibilidades para } \\
\text { ambos os tipos de empreendedor }\end{array}$ \\
\hline Relacionamento com o setor público & $\begin{array}{l}\text { Depende de defesa legal } \\
\text { conseguida com favores do } \\
\text { estado para ter vantagem } \\
\text { competitiva de longa duração }\end{array}$ & $\begin{array}{l}\text { Não precisa de intervenção estala } \\
\text { para proteger seu negócio, } \\
\text { geralmente enfrenta incerteza } \\
\text { regulatória }\end{array}$ \\
\hline $\begin{array}{l}\text { Tipo de empreendedor e relação com } \\
\text { a FPP }\end{array}$ & $\begin{array}{l}\text { Empreendedor, trabalha } \\
\text { dentro da FPP previamente } \\
\text { existente }\end{array}$ & $\begin{array}{l}\text { Empreendedor-Promotor, expande } \\
\text { a FPP existente }\end{array}$ \\
\hline
\end{tabular}

Fonte: Os autores.

A Tabela 1 mostra a coerência entre os estudos em ME e empreendedorismo quando se adota o ponto de vista da inovação. Com esta em mãos, os pesquisadores em ME podem 
diversificar o seu campo de estudo ao dar maior atenção aos empreendedores como responsáveis pelas iniciativas de marketing estratégico e de posicionamento das organizações no mercado. Para fazer isso, porém, será necessária uma modificação importante no método atualmente mais aceito em marketing. $\mathrm{O}$ uso da teoria empreendedorial da firma implica em adotar o individualismo metodológico para dar suporte às teorias previamente existentes que auxiliam na análise do marketing estratégico, quais sejam: a IBV, a SCM e a RBV+DC.

\section{Conclusões e pesquisas futuras}

Day \& Wensley (1983) afirmam que as disciplinas de marketing estratégico e estratégia são muito próximas. Davidsson (2016) sugere que há uma sobreposição proposital entre os pesquisadores em empreendedorismo e estratégia. $\mathrm{O}$ presente trabalho concorda com ambos. $\mathrm{O}$ trabalho contribui com desenvolvimentos recentes (Schoemaker \& Day, 2018) que evidenciam a importância do fator humano para a inovação em ambientes de incerteza.

Além do mais, ao adotar a teoria empreendedorial da firma (Bylund, 2016; Foss \& Klein, 2012), fundada em teoria econômica sólida, o trabalho dá maior substancia teórica para a teoria em marketing estratégico, ao sobrepujar o problema de falta de uma teoria do mercado em marketing sugerido por Vargo (2018, p. 732).

Existe a necessidade de melhor compreender o papel do marketing, e do marketing estratégico em particular, na inovação. O ponto de vista do empreendedor fornece uma saída interessante que abre caminhos para diversas discussões. Esse trabalho demonstra que a inovação é inerente ao marketing e que é especialmente importante para o marketing estratégico. A parte mais central do marketing trata de fazer coisas para servir a um mercado e obter lucro nesse processo, a causa fundamental da inovação é, em essência, a mesma. As inovações existem porquê pessoas anteveem melhores possibilidades no futuro para si e para outros indivíduos e por isso organizam firmas para desenvolver soluções e oferecer produtos para mercados que eles imaginam possam ser lucrativos. Alguns estudos em empreendedorismo chamam de "precisão empática" (empathic accuracy) e muitas conexões entre essa linha de pesquisa e o ME existem e ainda devem ser reveladas e exploradas (veja, por exemplo Mcmullen, 2015, p. 670).

Em virtude do dinamismo do mercado, as organizações como um todo devem ter na inovação uma necessidade. É dever do marketing estratégico lidar com a constante necessidade de mudança. Ao mesmo tempo, o empreendedorismo é tido como mais do que um simples ato ou atividade, ele deve ser visto como uma postura estratégica (Wales, 2016, p. 2) que guia a 
mepresa em todo a sua existência. Estas conexões também merecem maior atenção dos acadêmicos.

Uma consequência dos resultados deste trabalho é que parte dos estudos em estratégia pertence à área de inovação, como alguns autores já apontam (Alvarez, 2003; Minniti, 2003). Além disso, a existência de cátedras universitárias que lidam com estratégia, inovação e empreendedorismo ao mesmo tempo fornece suporte anedótico a tal conclusão e à abordagem adotada por este trabalho.

O trabalho também permite dizer que, quando analisado de um ponto de vista puramente teórico, o empreendedor Kirzneriano pode ser considerado um caso especial do empreendedor de F\&K. Ao considerar estes como dois pólos extremos de um contínuo a análise e a discussão ficam facilitadas, além do que, esta abordagem nos permite construir pontes entre as literaturas de forma a mostrar, pedagogicamente, os pontos de contato e as diferenças, o que aponta para outras possíveis perguntas de pesquisa.

Quanto a desenvolvimentos futuros, é necessário melhor compreender como empreendedores lidam com inovação em empresas de diversas indústrias e tamanhos enquanto tem que enfrentar os diferentes limites e incentivos inerentes a cada um desses ambientes (Barney, Foss, \& Lyngsie, 2018). Neste sentido, em grandes ambientes organizacionais, gestores deveriam ter o poder e as responsabilidades de agir de maneira empreendedora, se este for o objetivo da firma, assim, deve-se apontar para tais posições pessoas que tenham características de empreendedores (Sarasvathy, 2009). Ao fazer isso, a empresa estará ajudando a cumprir com seu direcionamento estratégico. Também é necessário compreender quais seriam os incentivos intraorganizacionais que mais fariam com que uma atitude empreendedora possa florescer. Os decisores em posições superiores a estes administradores precisam saber das possibilidades de insucesso inerentes aos esforços de inovação. Alguns desenvolvimentos começam a explorar estas conexões (D'Andrea \& Luce, 2020), mas resta muito a fazer para melhor compreender as conexões entre a teoria do empreendedor baseada em julgamento e a literatura em capacidades dinâmicas. Esta linha de pesquisa pode ajudar a compreender como o julgamento empreendedor ajuda a criar as capacidades dinâmicas e, em consequência, levaria a uma melhor compreensão de como os (proxy) empreendedores influenciam os esforços de inovação nas diferentes organizações. Ao explorar estas conexões, os pesquisadores podem se tornar mais capazes de compreender e influenciar a criação de vantagem competitiva, incluindo a facilitação da compreensão de como a Orientação empreendedora pode ser sustentada nas organizações, mesmo depois de seu crescimento e burocratização. 
Estudos empíricos em organizações menores, nas quais o empreendedor é mais diretamente responsável pelas ações de marketing estratégico, ajudarão a melhor compreender as lacunas que restam e que foram em parte apontadas neste trabalho. Tal mensuração certamente ajudará no avanço da compreensão deste fenômeno. Uma possibilidade seria tentar investigar como características cognitivas do empreendedor estão conectadas à criação das capacidades dinâmicas de sensing e sizing as quais são diretamente ligadas às decisões de marketing estratégico e posicionamento de mercado.

Em complemento, o uso de painéis seria especialmente interessante para testar a estrutura aqui sugerida. Por exemplo, seria interessante acompanhar a tentativa de transformação de uma empresa guiada pelo mercado (Market Driven) am uma que guia o mercado (Market Driving) baseada em julgamento empreendedor e capacidades dinâmicas. Além disso, acompanhar atores em organizações para entender como estas empresas se comportam e mudam de comportamento ao longo do tempo, buscando compreender se estas empresas tendem a se distanciar das ideias do empreendedor. Isto ajudaria a entender melhor como as organizações, os empreendedores e a inovação como um todo e como esses processos ocorrem e se desenvolvem nas organizações.

Por razões pedagógicas, seria importante explorar casos que apresentem os dois tipos de empreendedores, explicando em qual arranjo institucional eles são mais propensos a surgir. Os fundamentos teóricos sugerem que empreendedores Kirznerianos seriam mais comuns em ambientes menos dinâmicos, nos quais os recursos não são tão abundantes e a cultura é menos aberta ao dinamismo; regiões em desenvolvimento e pobres, assim como os setores de baixa carga tecnológica da economia são candidatos potenciais. Quando aos empreendedores do tipo $\mathrm{F} \& \mathrm{~K}$, estes seriam mais comuns em locais nos quais os recursos (inclusive os financeiros) são mais abundantes e mais diversos, e em ambientes nos quais os processos produtivos são mais longos e diversificados e nos quais existe capital disponível para experimentos incomuns, naturalmente mais incertos. Isto pode explicar os motivos pelos quais inovações mais disruptivas tendem a aparecer em algumas áreas geográficas específicas. Estas conclusões teóricas devem ser investigadas empiricamente.

Uma sugestão adicional é utilizar os construtos já conhecidos e testados de capacidades dinâmicas e conectá-los àqueles já testados de empreendedorismo como entendido por F\&K. Ao fazer isso seria possível descobrir as conexões entre as duas literaturas e compreender mais profundamente quais são as influências. Também é possível explorar as conexões entre as quatro fontes possíveis de inovação e a influência dos empreendedores sobre cada uma delas. 
Em virtude das dependências adquiridas ao longo da história da organização, a teoria indica que as fontes de inovação hard (produtos e processos) seriam menos influenciáveis pelo empreendedor, enquanto que as fontes de inovação soft (administração e marketing) seriam mais facilmente influenciáveis por conta da sua menor dependência em fatores físicos e capital financeiro. Ao mesmo tempo, fatores culturais ligados à parte soft tendem a ser muito difíceis de mudar.

Outro ponto de atenção pode tentar encontrar maneiras de conectar a necessidade de inovação com as quatro áreas clássicas das organizações (operações, finanças, pessoas e marketing) e como cada uma das possíveis fontes de inovação pode influenciar cada uma destas quatro áreas. Explorar esta idea levaria a uma maior compreensão das organizações como um todo, pois conectaria um entendimento clássico sobre as organizações com os empreendedores e como eles conseguem manter o sucesso ao longo do tempo.

Em conclusão, este trabalho mostrou que existe muita sobreposição entre estas literaturas que, até então, pareciam distantes, marketing estratégico e empreendedorismo. Ficou claro que a teoria econômica do empreendedor tem muito a colaborar com a compreensão das organizações no mercado e com sua constante busca por inovação e consequente busca de vantagem competitiva. Os pesquisadores em marketing estratégico devem superar a síndrome do "não inventado aqui" e usar o conhecimento vindo da literatura em empreendedorismo que usa o individualismo metodológico para melhorar a compreensão dos fenômenos sob seu escrutínio. Desta maneira o marketing estratégico entenderá de maneira mais completa como organizações, frutos da ação empreendedora, são forjadas ou forjam o mercado.

\section{Referências}

Alvarez, S. A. (2003). Resources and Hierarchies: Intersections between Entrepreneurship and Strategy. In Handbook of Entrepreneurship Research (pp. 247-263). New York: Springer-Verlag. https://doi.org/10.1007/0-387-24519-7_11

Alvarez, S. A., \& Barney, J. B. (2007). The Entrepreneurial Theory of the Firm. Journal of Management Studies, 44(7), 1057-1063. https://doi.org/10.1111/j.1467-6486.2007.00721.x

Alves, A. C., Barbieux, D., Reichert, F. M., Tello-Gamarra, J., \& Zawislak, P. A. (2017). Innovation and Dynamic Capabilities of the Firm: Defining an Assessment Model. Revista de Administração de Empresas, 57(3), 232-244. https://doi.org/10.1590/s0034759020170304

Barbieri, F. (2001). O processo de mercado na escola austríaca moderna. Biblioteca Digital de Teses e Dissertações da Universidade de São Paulo, São Paulo. https://doi.org/10.11606/D.12.2001.tde-20102001-144955 
Barney, J. B., \& Arikan, A. M. (2001). The Resource-based View: Origins and Implications. In M. A. Hitt, R. E. Freeman, \& J. S. Harrison (Eds.), The Blackwell Handbook of Strategic Management (pp. 124-188). Oxford, UK: Blackwell Publishers Inc. https://doi.org/10.1111/b.9780631218616.2006.x

Barney, J. B., Foss, N. J., \& Lyngsie, J. (2018). The role of senior management in opportunity formation: Direct involvement or reactive selection? Strategic Management Journal, 39(5), 1325-1349. https://doi.org/10.1002/smj.2768

Bocconcelli, R., Cioppi, M., Fortezza, F., Francioni, B., Pagano, A., Savelli, E., \& Splendiani, S. (2018). SMEs and Marketing: A Systematic Literature Review. International Journal of Management Reviews, 20(2), 227-254. https://doi.org/10.1111/ijmr.12128

BoStaph, S. (2013). Driving the market process: "Alertness" versus Innovation and Creative Destruction. Quarterly Journal of Austrian Economics, 16(4), 421-458.

Bylund, P. L. (2016). The problem of production: a new theory of the firm. Routledge.

Chandra, Y. (2018). Mapping the evolution of entrepreneurship as a field of research (19902013): A scientometric analysis. PLOS ONE, 13(1), e0190228. https://doi.org/10.1371/journal.pone.0190228

Cheah, H.-B. (1990). Schumpeterian and Austrian entrepreneurship: Unity within duality. Journal of Business Venturing, 5(6), 341-347. https://doi.org/10.1016/08839026(90)90010-Q

Chesbrough, H. (2003). Open innovation. Boston: Harvard Business School Press.

Christensen, C. M. (1997). The innovator's dilemma. Cambridge, Mass., USA: Harvard Business School Press.

D’Andrea, F. A. M. C., \& Luce, F. B. (2020). Entrepreneurs as real sources of Innovation A Strategic Marketing Perspective (Working Paper: Universidade Federal do Rio Grande do Sul).

D’Andrea, F. A. M. C., \& Mazzoni, J. F. (2019). For a less dramatic creative destruction. MISES: Interdisciplinary Journal of Philosophy, Law and Economics, 7(3). https://doi.org/10.30800/mises.2019.v7.1245

Davidsson, P. (2016). The field of entrepreneurship research: Some significant developments. In D. G. P. de Bögenhold, Dieter; Bonnet, Jean; Dejardin, Marcus; Lema (Ed.), Contemporary Entrepreneurship: Multidisciplinary Perspectives on Innovation and Growth (pp. 17-28). Cham: Springer. https://doi.org/10.1007/978-3-319-28134-6_2

Day, G. S., \& Wensley, R. (1983). Marketing Theory with a Strategic Orientation. Journal of Marketing, 47(4), 79. https://doi.org/10.2307/1251401

Driest, F. Van den, \& Weed, K. (2014). The ultimate marketing machine. Harvard Business Review, 92, 54-63. 
Dzogbenuku, R. K., \& Keelson, S. A. (2019). Marketing and entrepreneurial success in emerging markets: the nexus. Asia Pacific Journal of Innovation and Entrepreneurship, 13(2), 168-187. https://doi.org/10.1108/APJIE-12-2018-0072

Elias, S. R. S. T. A., Chiles, T. H., Li, Q., \& D’Andrea, F. A. M. C. (2020). Austrian Economics and Organizational Entrepreneurship: A Typology. Quarterly Journal of Austrian Economics, 23(3-4). https://doi.org/10.35297/qjae.010073

Fagerberg, J. (2006). Innovation: a guide to the literature. In J. Fagerberg, D. C. Mowery, \& R. R. Nelson (Eds.), The Oxford handbook of innovation (pp. 1-26). Oxford University Press.

Falcão, R. F., Ikeda, A. A., \& Campomar, M. C. (2017). Is Marketing Losing its Identity? A Bibliometric Review. Revista Brasileira de Marketing, 16(02), 154-167. https://doi.org/10.5585/remark.v16i2.3450

Finoti, L. L., Didonet, S. R., Toaldo, A. M. M., \& Costa, J. C. N. da. (2018). A Influência da Inovatividade no Processo de Estratégia de Marketing e o Impacto sobre o Desempenho Organizacional: Evidências do Setor TIC. Revista Brasileira de Marketing, 17(02), 166186. https://doi.org/10.5585/remark.v17i2.3521

Foss, N. J., \& Klein, P. G. (2012). Organizing entrepreneurial judgment : a new approach to the firm. Cambridge University Press.

Foss, N. J., \& Klein, P. G. (2017). Entrepreneurial Discovery or Creation? In Search of the Middle Ground. Academy of Management Review, 42(4), 733-736. https://doi.org/10.5465/amr.2016.0046

Germann, F., Ebbes, P., \& Grewal, R. (2015). The Chief Marketing Officer Matters! Journal of Marketing, 79(3), 1-22. https://doi.org/10.1509/jm.14.0244

Ghauri, P., Wang, F., Elg, U., \& Rosendo-Ríos, V. (2016). Market driving strategies: Beyond localization. Journal of Business Research, 69(12), 5682-5693.

https://doi.org/10.1016/J.JBUSRES.2016.04.107

Hill, J., \& Wright, L. T. (2000). Defining the Scope of Entrepreneurial MArketing: A Qualitative Approach. Journal of Enterprising Culture, 08(01), 23-46. https://doi.org/10.1142/S0218495800000036

Holcombe, R. G. (1999). Equilibrium Versus the Invisible Hand. The Review of Austrian Economics, 12(2), 227-243. https://doi.org/10.1023/A:1007820310502

Homburg, C., Vomberg, A., Enke, M., \& Grimm, P. H. (2015). The loss of the marketing department's influence: is it really happening? And why worry? Journal of the Academy of Marketing Science, 43(1), 1-13. https://doi.org/10.1007/s11747-014-0416-3

Houston, F. S. (1986). The Marketing Concept: What it is and What it is Not. Journal of Marketing, 50(2), 81-87. https://doi.org/10.1177/002224298605000207 
Huerta de Soto, J. (2009). The theory of dynamic efficiency. Routledge.

Hultman, C. M., \& Hills, G. E. (2011). Influence from entrepreneurship in marketing theory. Journal of Research in Marketing and Entrepreneurship, 13(2), 120-125. https://doi.org/10.1108/14715201111176408

Hunt, S. D. (2002). Foundations of marketing theory: toward a general theory of marketing. Armonk N.Y.: M.E. Sharpe.

Hunt, S. D. (2015). The theoretical foundations of strategic marketing and marketing strategy: foundational premises, R-A theory, three fundamental strategies, and societal welfare. $A M S$ Review, 5(3-4), 61-77. https://doi.org/10.1007/s13162-015-0069-5

Hunt, S. D. (2018). Advancing marketing strategy in the marketing discipline and beyond: from promise, to neglect, to prominence, to fragment (to promise?). Journal of Marketing Management, 34(1-2), 16-51. https://doi.org/10.1080/0267257X.2017.1326973

Jaworski, B., Kohli, A. K., \& Sahay, A. (2000). Market-Driven Versus Driving Markets. Journal of the Academy of Marketing Science, 28(1), 45-54. https://doi.org/10.1177/0092070300281005

Keyhani, M., \& Lévesque, M. (2016). The Equilibrating and Disequilibrating Effects of Entrepreneurship: Revisiting the Central Premises. Strategic Entrepreneurship Journal, 10(1), 65-88. https://doi.org/10.1002/sej.1210

Kim, W. C., \& Mauborgne, R. (2004). Blue Ocean Strategy. Harvard Business Review, (October). Retrieved from https://hbr.org/2004/10/blue-ocean-strategy

Kirzner, I. M. (1973). Competition and entrepreneurship. University of Chicago Press.

Kirzner, I. M. (2009). The alert and creative entrepreneur: a clarification. Small Business Economics, 32(2), 145-152. https://doi.org/10.1007/s11187-008-9153-7

Klein, P. G. (2017). An Austrian Perspective on Firms and Markets: My Contributions to Entrepreneurship Theory. In D. B. Audretsch \& E. E. Lehmann (Eds.), The Routledge Companion to the Makers of Modern Entrepreneurship (pp. 146-153). New York, NY, USA: Routledge.

Knight, F. H. (1921). Risk, Uncertainty, and Profit. Boston \& New York: Houghton Mifflin Company.

Kohli, A. K., \& Jaworski, B. J. (1990). Market Orientation: The Construct, Research Propositions, and Managerial Implications. Journal of Marketing, 54(2), 1. https://doi.org/10.2307/1251866

Kumar, V., Jones, E., Venkatesan, R., \& Leone, R. P. (2011). Is Market Orientation a Source of Sustainable Competitive Advantage or Simply the Cost of Competing? Journal of Marketing, 75(1), 16-30. https://doi.org/10.1509/jm.75.1.16 
Kuratko, D. F., Morris, M. H., \& Schindehutte, M. (2015). Understanding the dynamics of entrepreneurship through framework approaches. Small Business Economics, 45(1), 1-13. https://doi.org/10.1007/s11187-015-9627-3

Lachmann, L. M. (1977). Ludwig von Mises and the market process. In Capital, Expectations and the Market Process (pp. 181-193). Kansas City: Sheed, Andrews and McMeel.

Lachmann, L. M. (1986). The Market as an Economic Process. New York: Oxford: Basil Blackwell.

Lieberman, M. B., \& Montgomery, D. B. (1998). First-mover (dis)advantages: retrospective and link with the resource-based view. Strategic Management Journal, 19(12), 1111-1125. https://doi.org/10.1002/(SICI)1097-0266(1998120)19:12<1111::AID-SMJ21>3.0.CO;2-W

Lundvall, B.-Å., \& Borrás, S. (2005). Science, technology, and innovation policy. In Oxford handbook of innovation (pp. 599-631). Oxford University Press.

Maciariello, J. (2009). Marketing and innovation in the Drucker Management System. Journal of the Academy of Marketing Science, 37(1), 35-43. https://doi.org/10.1007/s11747-008-0098-9

Malhotra, N. K. (2018). Marketing Research: Current State and Next Steps. Revista Brasileira de Marketing, 17(05), 647-665. https://doi.org/10.5585/bjm.v17i5.4172

Matos, C., Matos, C. A. de, Martins, F. E., Rosa, M. B. da, \& Bernardon, R. (2018). Os Efeitos do Alinhamento entre Práticas de Marketing e Estratégia de Negócios no Desempenho das Empresas. Revista Brasileira de Marketing, 17(6), 849-865. https://doi.org/10.5585/remark.v17i6.3774

Mazzon, J. A. (2018). Using the Methodological Association Matrix in Marketing Studies. Revista Brasileira de Marketing, 17(05), 747-770. https://doi.org/10.5585/bjm.v17i5.4175

Mcmullen, J. S. (2015). Entrepreneurial judgment as empathic accuracy: a sequential decision-making approach to entrepreneurial action. Journal of Institutional Economics, 11(3), 651-681. https://doi.org/10.1017/S1744137413000386

Miles, E. W. (2016). Critical Juncture III: The 1959 Foundation Reports-Throwing Out the Baby with the Bath Water? In The Past, Present, and Future of the Business School (pp. 65-76). Cham: Springer International Publishing. https://doi.org/10.1007/978-3-31933639-8_8

Miles, M., Gilmore, A., Harrigan, P., Lewis, G., \& Sethna, Z. (2015). Exploring entrepreneurial marketing. Journal of Strategic Marketing, 23(2), 94-111. https://doi.org/10.1080/0965254X.2014.914069

Minniti, M. (2003). Entrepreneurship Studies: A Stocktaking (pp. 9-37). https://doi.org/10.1016/S1529-2134(03)06002-2 
Mizik, N., \& Jacobson, R. (2003). Trading off between Value Creation and Value Appropriation: The Financial Implications of Shifts in Strategic Emphasis. Journal of Marketing, 67(1), 63-76. https://doi.org/10.1509/jmkg.67.1.63.18595

Nobrega, C., \& Lima, A. R. de. (2010). INNOVATRIX: inovação para não gênios. Rio de Janeiro, RJ, Brasil: Agir.

Oliveira, S. L. I. de, Moretti, S. L. A., \& Silva, L. A. (2017). Os Primeiros Estudos em Marketing: A Influência da Filosofia e das Ciências nos Primeiros Estudos em Marketing Uma Análise da Obra Marketing Problems de Melvin T. Copeland. Revista Brasileira de Marketing, 16(04), 502-519. https://doi.org/10.5585/remark.v16i4.3508

Packard, M. D., \& Bylund, P. L. (2018). On the relationship between inequality and entrepreneurship. Strategic Entrepreneurship Journal, 12(1), 3-22.

https://doi.org/10.1002/sej.1270

Pavitt, K. (2006). Innovation Processes. In J. Fagerberg, D. C. Mowery, \& R. R. Nelson (Eds.), The Oxford Handbook of Innovation. Oxford University Press. https://doi.org/10.1093/oxfordhb/9780199286805.003.0004

Peng, M. W. (2002). Towards an Institution-Based View of Business Strategy. Asia Pacific Journal of Management, 19(2/3), 251-267. https://doi.org/10.1023/A:1016291702714

Phelan, S. E. (2016). Austrian theories of entrepreneurship: Insights from complexity theory. The Review of Austrian Economics, 29(3), 277-297. https://doi.org/10.1007/s11138-0150302-3

Porter, M. E. (1985). The Competitive Advantage: Creating and Sustaining Superior Performance. Los Angeles, CA, USA: The Free Press.

Porter, M. E. (1996). What is strategy? Harvard Business Review, (Nov-Dez), 61-78.

Powell, B. (2007). Making Poor Nations Rich: Entrepreneurship and the Process of Economic Development (Stanford E). Boston, Massachussets: Stanford University Press.

Reibstein, D. J., Day, G. S., \& Wind, J. (2009). Guest Editorial: Is Marketing Academia Losing Its Way? Journal of Marketing, 73(4), 1-3. https://doi.org/10.1509/jmkg.73.4.1

Rothbard, M. N. (1976). Praxeology: The methodology of Austrian economics. In The Foundations of Modern Austrian Economics (pp. 19-39).

Rothbard, M. N. (2004). Man, Economy, and State A Treatise on Economic Principles with Power and Market Government and the Economy (Second). Auburn, Alabama, USA: Ludwig von Mises Institute.

Sarasvathy, S. D. (2009). Effectuation : elements of entrepreneurial expertise. Elgar.

Schoemaker, P. J. H., \& Day, G. S. (2018). Strategic Actions in the Face of Uncertainty. Revista Brasileira de Marketing, 17(05), 700-729. https://doi.org/10.5585/bjm.v17i5.4178 
Schumpeter, J. A. (1942). Capitalism, Socialism and Democracy. New York, NY, USA: Harper and Row.

Senge, P. (1994). The Fifth Discipline: The art and practice of the learning organization. Random House.

Shaw, E. H., Jones, D. G. B., \& McLean, P. A. (2011). The Early Schools of Marketing Thought. In P. Maclaran, M. Saren, B. Stern, \& M. Tadajewski (Eds.), The SAGE Handbook of Marketing Theory (pp. 27-41). London, UK: SAGE Publications Ltd. https://doi.org/10.4135/9781446222454.n2

Srivastava, R. K., Shervani, T. A., \& Fahey, L. (1999). Marketing, Business Processes, and Shareholder Value: An Organizationally Embedded View of Marketing Activities and the Discipline of Marketing. Journal of Marketing, 63(4_suppl1), 168-179. https://doi.org/10.1177/00222429990634s116

Stokes, D. (2000). Putting Entrepreneurship into Marketing: The Processes of Entrepreneurial Marketing. Journal of Research in Marketing and Entrepreneurship, 2(1), 1-16. https://doi.org/10.1108/14715200080001536

Teece, D. J. (2007). Explicating dynamic capabilities: the nature and microfoundations of (sustainable) enterprise performance. Strategic Management Journal, 28, 1319-1350. https://doi.org/https://doi.org/10.1002/smj.640

Thiel, P. A., \& Masters, B. (2014). Zero to one: Notes on startups, or how to build the future. Broadway Business.

Varadarajan, R. (2010). Strategic marketing and marketing strategy: Domain, definition, fundamental issues and foundational premises. Journal of the Academy of Marketing Science, 38(2), 119-140. https://doi.org/10.1007/s11747-009-0176-7

Varadarajan, R. (2015). Strategic marketing, marketing strategy and market strategy. AMS Review, 5(3-4), 78-90. https://doi.org/10.1007/s13162-015-0073-9

Varadarajan, R. (2019). Theoretical underpinnings of research in strategic marketing: a commentary. Journal of the Academy of Marketing Science, 47(1), 30-36. https://doi.org/10.1007/s11747-018-0612-7

Vargo, S. L. (2018). Marketing Relevance Through Market Theory. Revista Brasileira de Marketing, 17(05), 730-746. https://doi.org/10.5585/bjm.v17i5.4177

Wadhwani, R. D., \& Lubinski, C. (2017). Reinventing Entrepreneurial History. Business History Review, 91(04), 767-799. https://doi.org/10.1017/S0007680517001374

Wales, W. J. (2016). Entrepreneurial orientation: A review and synthesis of promising research directions. International Small Business Journal: Researching Entrepreneurship, 34(1), 3-15. https://doi.org/10.1177/0266242615613840 
Weerawardena, J., \& O'Cass, A. (2004). Exploring the characteristics of the market-driven firms and antecedents to sustained competitive advantage. Industrial Marketing Management, 33(5), 419-428. https://doi.org/10.1016/J.INDMARMAN.2003.07.002

Whitler, K. A., \& Morgan, N. (2017). Why CMOs never last and what to do about it. Harvard Business Review, 95(4), 47+-.

Wiklund, J., Davidsson, P., Audretsch, D. B., \& Karlsson, C. (2011). The Future of Entrepreneurship Research. Entrepreneurship Theory and Practice, 35(1), 1-9. https://doi.org/10.1111/j.1540-6520.2010.00420.x 